\title{
RESTRICTIONS ON DisPosition IN THE OIL AND GAS INDUSTRY: THE EXTINCTION OF THE SPECIES?
}

\author{
Gordon L. TaRnowsky, Miles F. PITtMan, and Carolyn WILTON
}

Restrictions on disposition in the oil and gas industry. predominanty rights of first refusal. con create significant uncertainties in oil and gas transactions. particularly complex ones. In an effirt or discern trends in judicial approaches. the anhors review Canadianjurisprudence dealing with difficudt rights of first refusal issues against the backdrop of academic and professional commentary in the 199/s, which promoted the establishment of judicially developed "default rules" to ensure imterpretive ceriainy. The authors postulate that parties ought not to presume the existence or application of "defaull rules" in the interpretation and application of restrictions on disposition. based on the jurisprudence. Rather. parties ought to focus on considered drafting when preparing agreements and. where uncerfainties arise in the application of provisions, ought to contemplate the reasonable expectations of the parties to the agreement.
Les restrictions à l'unilisation dans le secteur pétrolier at gazier. qui consistent essemicllement dans le droit de premier refus, peuvent donner lieu à de séricuses incertitudes pour les iransactions pétrolicres ef gazières, surtout dans le cas de transactions complexes. Dans le bu de distinguer les tendances dans les approches judiciaires, les aureurs examinem la jurisprudence canadienne traitan des questions difficiles de droits de premier refus avec pour voile de fond les commentaires universitaires et professionnels des années 1990 quifaisaient valoir l'èrablissement de "règles par défaut ", créces impartialement en ive d'une certinude interpretation. Les auteurs posent comme principe que les parties ne devraien pas supposer l'existence de l'application de a règles par defaut "dans l'interpretation et l'applicution des restrictions $\dot{a}$ l'urilisation basees sur la jurisprudence. Les parties devraient plutôt se concentrer sur des textes considérés au moment de préparer les ententes et, en cas d'incertitudes dans l'application des dispositions, elles devraient envisager les attemtes raisonnables des parties à l'entente.

\section{TABLE of Contents}

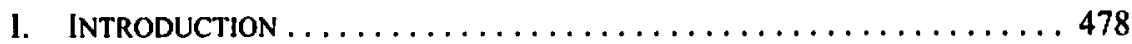

II. LEgAL NATURE AND PURPOSE OF ROFRs ................ 479

III. COMPLEX TRANSACtIONS - Discerning TRENDS

IN THE CASE LAW . . . . . . . . . . . . . . . . . . . . . 482

A. The "Default Rule" APProaCh $\ldots \ldots \ldots \ldots \ldots \ldots \ldots \ldots \ldots, 482$

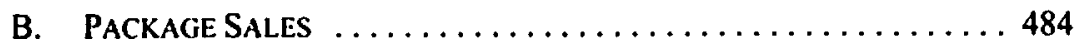

C. Non-Cash Consideration ................... 497

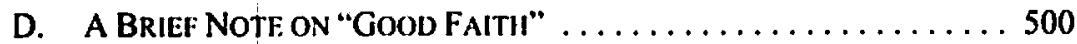

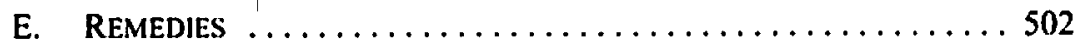

IV. SPECIFIC TRANSACTIONS OF INTEREST $\ldots \ldots \ldots \ldots \ldots \ldots \ldots \ldots \ldots, \ldots \ldots \ldots$

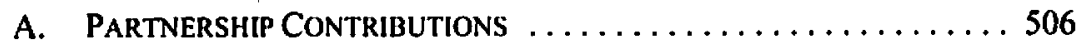

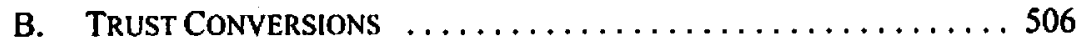

V. CONCLUSION $\ldots \ldots \ldots \ldots \ldots \ldots \ldots \ldots \ldots \ldots \ldots \ldots \ldots \ldots \ldots \ldots \ldots \ldots$

Gordon Tarmowsky and Miles Pittman, Parners, and Carolyn Wilton, Associate, Fraser Milner Casgrain LLP, Calgary, Alberta. The authors wish to acknowledge the contributions, insights, and restarch assistance of the lawyers and students at Fraser Milner Casgrain LLP who contributed to the preparation of this article, particularly Cori Ghitter and Peter Vetsch, Student-at-Law. 


\section{INTRODUCTION}

Restrictions on disposition take a variety of forms in the oil and gas industry and they invariably create vexing issues in transaction planning and exccution. A common scenario: a party wishes to enter into a complex transaction, but an agreement governing some of the important assets involved contains a right of first refusal (ROFR) in favour of a third party that may be triggered if the transaction proceeds as contemplated. If the ROFR is triggered and exercised upon, the transaction may unwind or there may be a significant reduction to the consideration payable by the third party. In either event, the outcome is unacceptable. The uncertainty of outcome itself can add to the complexity of the transaction.

Court involvement in ROFR interpretation is relatively rare in the oil and gas industry in Canada, notwithstanding the thousands of ROFRs that exist industry-wide. This may suggest that industry participants are more likely to ascribe a common industry view as to the intended application of ROFRs that reflects the practicality of the situation and the results. Alternatively, it may suggest that the outcome of litigation is so uncertain that parties facing complex issues are generally not prepared to run the risks of litigation where the potential implications of losing, on either side, can be substantial. A potential corollary of this situation is that the use of ROFRs, which have proven to be the most frequently litigated form of restriction on disposition, may be falling into disuse in the industry. ${ }^{1}$

ROFRs received significant attention in academic and professional commentary in Canada in the 1990s. ${ }^{2}$ This article does not duplicate the thorough reviews undertaken in those articles. Instead, its first purpose is to review Canadian jurisprudence dealing with restrictions on disposition to determine whether any trends are emerging. In this context, the more problematic scenarios presented by package sales $^{3}$ and non-cash consideration form the focus of the analysis. The second purpose of the article is to assess whether the case law reflects the adoption of a "default rule" in respect of restrictions on disposition as had been promoted by some academic and professional commentary. ${ }^{4}$ In concluding that the case law does not support the "default rule" approach, the article postulates instead that the

$1 \quad A$ decline in the use of ROFRs in joint venture relationships was suggested in Don Greenficld \& Jay Todesco, "Fundamental Aspects of Oil and Gas Law Revisited" (2004) 42 Alta. L. Rev. 75 at 97. This has also been suggested to be the case in respect of the oil and gas industry in the United States. Sec, e.g., Terry I. Cross, "The Ties That Bind: Precmptive Rights and Restraints on Alienation That Commonly Burden Oil and Gas Properties" (1999) 5 Tex. Wesleyan L. Rev. 193 at 195; William A. Keele, "The Oil and Gas Joint Operating Agreement: Unraveling Sume Knots" (1990) 36 Rocky Mtn. Min. L. Inst. 18-1 at 18-18; and G.F. Kutzschbach, "Operating Agreement Considerations in Acquisitions of Producing Properties" (1985) 36 Inst. on Oil and Gas Law and Taxation 7-1 at 7-3.

: See in particular Keith T. Smith \& Shawn H.T. Denstedt, "Preemptive Rights and the Sale of Resource Properties: Practical Problems and Solutions" (1992) 30 Alta. L. Rev. 57; Robert Flannigan, "The Legal Construction of Rights of First Refusal" (1997) 76 Can. Bar Rev. 1; Brian Beck \& Douglas G. Mills. "Rights of l:irst Refusal" (Paper presented to the Insight Conference entitled "Exercising Due Diligence in Oil and Gas Property Transactions," Calgary, 24-25 February 1998) (Toronto: Insight Press, 1998); and Clifford D. Johnson \& David J. Stanford, "Rights of First Refusal in Oil and Gas Transactions: $A$ Progressive Analysis" (1999) 37 Alta. L. Rev. 316.

3 Transactions in which the ROF $R$ cncumbered assets are only part of a larger package of assets being translerred or disposed of, which properties are not burdened by the ROFR (but may be burdened by other ROFRs).

$4 \quad$ Sce Flannigan, supra note 2; Beck \& Mills, supra note 2; and Bernard Daskal, “Rights of First Refusal and the Package Deal" (1995) 22 Fordham Urb. L.J. 461. 
expectations of the industry and the preponderance of the jurisprudence, with some exceptions, support a traditional contractual interpretation approach as set out by the Alberta Court of Appeal in Mesa Operating Ltd. v. Amoco Canada Resources Ltd. ${ }^{5}$ This case stands for, among other thing, the proposition that the language of the restriction should be interpreted on its face tojgive effect to the intentions of the parties having regard to their reasonable expectations given the commercial context in which the contract was entered. In this approach, the strict language of the contract may be tempered by the concept of "reasonable expectations" to avoid results that are demonstrably offensive to the purpose of, and expectations generated by, the ROFR. Finally, the article examines two newer types of transactions in the industry, trust conversions and partnership contributions, and their potential to give rise to ROFR issues.

Drawing on this analysis, the article concludes that it is unlikely the judicial treatment of restrictions on disposition is going to produce the degree of certainty of results that most industry parties would prefer. Typically, each case will be dealt with on its specific facts and circumstances. Accordingly, it is suggested that parties who want to achieve a degree of certainty with respect to the interpretation and application of restrictions on disposition generally should focus their drafting efforts on ways in which their intentions may be made more self-evident ${ }^{\text {}}$ and, wherever possible, to update their existing agreements to reflect the current state of the relationship between the parties. Absent these efforts, the combination of this uncertainty with the desire in the industry for flexibility may lead to restrictions on disposition falling further out of favour.

\section{Legal Nature, and PURPose, of ROFRS}

Rights of first refusal, also called preferential purchase rights, pre-emptive rights, or rights of first purchase, can be used to encumber many types of property, from contractual interests to land to shares in a corporation. The right is, in essence, a contingent option to purchase. Upon the occurrence of the triggering event, usually an offer from a third party to purchase the property that the owner is willing to accept, the holder of the option may prevent the sale to the third party by matching the terms and conditions of the offer. Canadian courts have characterized ROFR clauses as a form of negative covenant pursuant to which the owner agrees not to substitute a third party as owner without first permitting the right holder, by Sce also Scurry-Rainbow v. Kasha (1996), 184 A.R. 177 (C.A.). leave to appeal to S.C.C. refused, [1996] S.C.C.A. No. 391 (QL).

- This concept is discussed further below in the section entitled "A Brief Note on Good liaith," and its application is referted to herein as the pusposive approach to interpretation.

It is recognized that, for a variety of reasons, greater focus at the drafling stage may not always be desirable or feasible (see in particular, Beck \& Mills, supra note 2 at 8-10). However, while Beck and Mills acknowledged that it would be wrong to imply that any clear "default rules" exist in the Canadian oil and gas industry, they appear to favour the approach of endeavouring to discem such rules over the application of a purposive interpretive approach. 
meeting the proposed terms of sale, to acquire the owner's interest. ${ }^{8}$ Upon the occurrence of the triggering event the negative covenant "ripens" into an option to purchase."

In the oil and gas industry, ROFRs have historically been included in various forms of joint venture agreements, yet there is a dearth of industry-specific case law that addresses even the most common ROFR issues. The most frequent situation in which ROFRs have been litigated in Canada is where they are included in a lease of commercial property. While such cases are instructive, ${ }^{10}$ there is a fundamental difference between the leasehold situation and the typical oil and gas context: in the former the ROFR is unilateral, whereas in the latter it is almost always mutual. That is, in the oil and gas context the ROFR typically encumbers the interests of all owners such that all are faced with both the encumbrance and the right. This fact may assist in explaining the relatively infrequent involvement of the courts in oil and gas ROFR disputes. Parties that are both bound by and beneficiaries of the right are perhaps more cautious in the assertion of extreme positions on either side of the debate. While this may engender an industry understanding with respect to the application of ROFRs in certain circumstances, that understanding may not be supported by the courts when called upon to resolve the issue."

In an oil and gas context, Canadian courts have generally expressed the view that the purpose of a ROFR is to protect the desire of joint owners not to be forced into joint ownership with another party against its will - often referred to as the "blackballing purpose." ${ }^{2}$ Although intuitively this may constitute a valid rationale in some circumstances, to the extent it is relied upon by the courts, they generally do so without any apparent supporting evidence. Notwithstanding this, courts have placed some significance on this as the purpose to be served by ROFRs in assessing whether a clause has been breached. ${ }^{13}$ Thus,

Canudion Long Island Petroleum Lud. v. Irving Industries Lud, [1975] 2 S.C.R. 715 at 735 [Canadian long [sland].

- Ibid. at 732; Flannigan, supra note 2 at 4. Although the Supreme Coun of Canada determined in Cumadian Long Island that ROFRs are not interests in land, some provinces have enacted legislation pursuant to which a ROFR is deemed to be an equitable interest in land in respect of which a caveat may be registered. In Alberta, see Law of Properly Act, R.S.A. 2000, c. L-7. s. 63( I), and in British Columbia, see Property Low' Act, R.S.B.C. 1996. c. 377, s. 9. Scenarios more comparable to the oil and gas industry context are arguably found in shareholder or other joint venture situations.

1 For a discussion of the impact of established industry practices on the interpretation of industry agreements, see Alicia K. Quesnel, "Modemizing the Property Laws That Bind Us: Challenging Traditional Property Law Concepls Unsuited to the Realities of the Oil and Gas Industry" (2003) 41 Alta. L. Rev. 159.

12 Cancedian long Island, supra note 8 at 728. See also Trimac Lid. v. CII. Inc. (1989), 99 A.R. 30 al 81 (Q.B.) [Trimac]. The term "blackballing purpose" was used in John S. Sellingsloh, "Preferential Purchase Rights" (1966) 11 Rocky Mtn. Min. L. Inst. 35 at 42.

For example, in Trimac, ibid, the Court relied upon this purpose in assessing whether a ROFR in a two sharcholder situation had been triggered by a proposed disposition of sharcholder $A$ 's 50 pereent interest to a third party where disposition was conditional on shareholder B's 50 pereent interest first being obtained by shareholder A under a shot-gun buy-stell clause. The Cour held al 81 : "Since the purpose of [the ROFR clause] is to prevent a party from being forced into an undesired partnership, it is not breached by any agreement that [shareholder $\Lambda$ reached with [the third party]. As [the third party] would not acquire any shares in [the corporation] until after [shareholder B] sold its interest, no partnership between [the third party] and [shareholder B] would ever develop." In Chase Manhartan Bank of Canada v. Sunoma Energy Corp., 2001 ABQB 142, 283 A.R. 260 at para. 16, aff d 2002 ABCA 286, 317 A.R. 308 [Chase], the Court presumed that this was the intent of the parties in including the 
a court's perception of the purpose of a ROFR will have an impact on its interpretation of the clause and its determination as to whether it applies to the particular disposition in issuc. As noted below in Part III.E, it may also have an impact on the remedy granted in the event of a breach. It is therefore a matter that should receive careful consideration both in the drafting stage and, if possible, ${ }^{14}$ when litigation arises. However, as noted by Daskal, it is usual that "provisions creating rights of first refusal are short on language. They neither state the intent of the parties expressly nor implicitly." intention of the parties is reflected, expressly or by implication, in the language employed. ${ }^{\text {th }}$ Indeed, the discernment of this intention is the function the courts are called upon to perform. Daskal's admonishment, however, highlights the importance and benefit of a clearer expression of purpose.

It is arguable that the "blackballing purpose" has more limited application in the oil and gas industry today. The proliferation of multiple party joint ventures, where the individual interests of some or all parties are not material to the manner in which the venture or assets are or may be operated, means that the identity of a joint owner (other than perhaps a joint owner with a controlling interest) is a less significant factor than it once was. This is particularly so with respect to facility agreements where many partics may acquire varying degrees of interests in the facilities. At a minimum, in the oil and gas industry today it cannot be assumed that this is the purpose, if even a purpose, for the inclusion of a ROFR in many agreements. Where a ROFR is included in an agreement today it may simply be included without thought as to why, ${ }^{17}$ or to provide the parties with an opportunity to increase the

ROFR clausc. Sec also DeBeers Camoda Inc. v. Shore Gold lnc., 2006 SKQB 154, 278 Sask. R. 226, where, among other reasoning, the Court relied upon the "blackballing purpose" of a ROFR as support for the conclusion that ereating a limiled cncumbrance on the owner's rights (in this case entering into a voting agreement) did not defeat the purpose of the ROFR and, therefore, doing so did not fall within the reasonable contemplation of the parties as a transaction that would be caught by the ROlik. But see Gaston Chagnon Property Lid. v. Spiropoulos (1999), 24 R.P.R. (3d) 52 (N.S.S.C.) where, on the facts of the case and in undertaking a purposive analysis of the ROFR. the Court concluded that the "blackballing purpose" had no application and, therefore, did not inform the proper determination of whether the ROFR applied to the transaction.

14 In litigating the interpretation of a contract, the ability to adduce extrinsic evidence is restricted by the parol evidence nule. For a comprehensive review of the law, see Tom F. Mayson. "The Use of Lxtrinsic Evidence in the Interpretation of Written Agrecments in Alberta" (2004) 42 Alta. L. Rev. 499. However, it may be possible to adduce some evidence of the circumstances surrounding the agreement that would assist in putting the ROFR clause in context. See, e.g., the decision in ADESA Auctions of Canade Corp. v. Sowhern Railway of British Columbia, 2001 BCSC 1421, 44 R.P.R. (3d) 260 [ADE.SA] where the Courn placed some significance on the evidence given by the ROFR holder as to the purpose served by the ROFRs it negotiated. However, if the purpose for the inclusion of a ROFR was considered important by one or more of the parties at the time of contracting. it would be far more effective to express more clearly in the agreement the intention behind the inclusion of the ROFR. Daskal, supra note 4 at 469 [footnotes omitted]. In this regard, Beck \& Mills, styro note 2 at 8 , have noted that "the purpose of a ROFR is by no means always self-evident, it is dilficult to deduce how the ROFR should operate in light of a particular set of facts" and that "[i]n any particular case. if more were known ahoul what the parties intended to achieve with their ROFR, it might be possible to deduce the correct answers to such questions" [foolnote omitted].

1) Parties may include them as boilerplate language or simply "tick-off" the ROFR option in standard form industry agreements such as "Altemate B" in cl. 2401 of the Canadian Association of Petroleum Landmen (CAPL), CAPL Operating Procedure (Calgary: CAPL, 1990) [1990 CAPL Opcrating Procedure] as a matter of standard policy or practice. 
quantum of their interest upon the proposed disposition by another joint owner, otherwise referred to as the "acquisition purpose."18

\section{Complex Transactions - Discerning Trends in the Case Law}

\section{A. THE "DEFAULt RULE" APPROACH}

While many issues can arise in dealing with ROFRs in straightforward asset sales in the oil and gas industry, generally speaking they do not appear to present significant difficulties for the parties involved. The industry is well versed in the common forms of ROFR clauses and is familiar with the concepts involved. To the extent difficult issues arise, it is where a transaction is complex or has characteristics that give rise to a genuine issue as to whether it would trigger a ROFR and, if so, the rights and duties of the vendor, the ROFR holder, and the third party. Although the case law considering such issues remains relatively sparse, the most frequent issues that have resulted in reported judicial decisions involve complex Iransactions such as package sales, and transactions where the consideration offered by the third party includes non-cash elements (both aspects often being present in complex transactions).

Package sales give rise to two dominant issues: (1) whether or not a package sale triggers a ROFR; and (2) if triggered, how are the terms and conditions, particularly the price, for the ROFR offer on the encumbered interests to be determined - generally referred to as the "allocation dilemma."19 Similar issues can arise in circumstances of third-party sales involving non-cash consideration: (1) whether the existence of non-cash consideration can effectively preclude the ROFR holder from exercising the ROFR; and (2) if not. and there is an express or implied obligation to attribute a value to the non-cash consideration, how is that value to be determined.

The resolution of such issues is, in the first instance, to be found in the express language of the agreement. ${ }^{20}$ For example, the 1990 CAPL Operating Procedure expressly deals with the situation where the consideration offered by the third-party purchaser cannot be matched in kind by the ROFR holder. ${ }^{21}$ In the absence of a definitive answer flowing from the contract language, the default rule approach dictates a presumptive interpretation and result.

See Sellingsloh, supra note 12. As noted in the discussion in Beck and Mills and the various articles referenced by them. there arc a variety of reasons that might support the acquisition purpose, such as leveraging the existing investment in acquired knowledge in the area, enhancing or acquiring a control position in the property, maintaining a link between a source of production and the product supplied and. in some cases, ensuring the creditworthiness of new participants (although this may be sufficiently served by consent provisions). Johnson \& Stanford, supro note 2 at 333.

As succinctly stated by Beck \& Mills, stupra note 2 at 11 , "the first rule in respect of any ROFR must always be, "read the contract.""

Sipra note 17. The 1990 CAPL Optrating Procedure included some modificalions to the language in the 1974 and 1981 CAPLs and may, in application, give rise to different results. As discussed further herein, however, such provisions do not avoid all uncertainty with respect to the non-cash consideration issues. See the discussion below at page 500 . 
Transactions involving package sales and non-cash consideration, perhaps more than any other scenario, pit an owner's right to alienate its property against the rights of the ROFR holder. In his 1997 article, Professor Flannigan suggested that while Canadian courts had yet to deal definitively with the issues, the trend was to find that package sales violate ROFRs, but that there was some hesitancy to award specific performance as a remedy."2 Drawing on Daskal's analysis of United States jurisprudence and his proposed "default rule," ${ }^{23}$ Flannigan argued in favour of the adoption of a "default rule" that (subject to an express provision otherwise) package sales should be treated as triggering ROFRs and that specific performance of the ROFR should be granted as the remedy with the price to the holder being established by the court at the "lair market value" of the subject property standing alone (i.e., without consideration of any synergistic gains or other price impacting factors, such as tax consequences, above the fair market value that may be obtained through the structure of the transaction). ${ }^{24}$ This approach was based on an underlying presumption that, in the authors' view, would constitute a surprising proposition to most participants in the oil and gas industry: that is, that owners of property, by including a ROFR in an agreement encumbering the property interest, thereby implicitly agree "to forego synergistic gains above the fair market value that might otherwise be available as a result of the structuring or packaging of the sale of the subject property."

Further, in the oil and gas industry valuation of property in a transaction, particularly in a bid context, frequently produces a wide range of values. ${ }^{26}$ It is not uncommon for large transactions that are part of a bid process to produce offers that vary by tens to hundreds of millions of dollars. Thus, the notion that there is an implicit agreed objective standard as to the manner in which value is to be determined for ROFR encumbered property is not reflective of the commercial reality within which these provisions operate.

Professor Flannigan also suggested that in the absence of a default rule of this nature, "[v]endors and third parties will continue, as they have, to arrange package sales in attempts

Flannigan, supra note 2 at 35-36.

$\therefore$ Daskal. supra note 4 at $478-501$. Daskal argued in favour of the development of a default rule and that the most appropriate approach would be to require an owner who receives an acceptable offer for a package deal to provide the ROIPR holder with an opportunity to purchase the burdened property at a reasonable price, a right that should be specifically enforceable. $A$ s is apparent, this view is similar to that advocated by Flannigan (the only apparent difference being the pricing standard of "lair and reasonable" versus "fair market value") (Flannigan, ibid. at 32). See also the summary ol" the Daskal analysis in Beck \& Mills, supro nole 2 at 52-56, where Beck and Mills considered Daskal's approach to be "consistent with the general experience and practice of oil-and-gas lawyers in Alberta, particularly in cases when the CAPL Operating Procedures govern" (at 56). Similar sentiments were expressed by Smith \& Denstedt stupra note 2 at 73.

24 Flannigan, ibid. al 32-33.

23 Ibid. at 33. Based on the authors" experience, this view is inimical to the practice and expectations in the oil and gas industry.

$\therefore \quad$ In Chase (C.A.), sippra note 13 at pura. 31, the Court noled that the "dramatic dilferctecs [among the various valuations in evidence] amply demonstrate the potential range of values that may be attached to oil and gas properties by potential purchasers." As Johnson \& Staniord, supra note 2 at 334 described: "The ROFR holder's pereeption of lair market value may not be even remotely elose lo the purchaser's notion of such value, i.e. what it would have been prepared to pay tor the property if it was sold on a stand-alone basis. Moreover, there may be a value enhancement resulting from the package deal that would not otherwise exist, such as access to processing lacilities and the like." 
to circumvent rights of first refusal."27 This implies that in many cases the sole purpose of package sales (or even $a$ purpose) is to defeat or avoid a ROFR. Again, this does not comport with the general practice in the oil and gas industry and certainly is not reflected by the majority of Canadian cases that have considered package sales (or similar) situations. Indeed, in the nine years since the publication of Professor Flannigan's article, the judiciary in Canada has generally not taken to the "default rule" construct.

In order to place recent Alberta (and Canadian) case law in context, it is necessary to appreciate the leading authorities that have acted as guideposts in the development of the law.

\section{B. Package Sales}

The most frequently cited, if not leading, package sale authority in Canada is the majority decision of the Ontario Court of Appeal in Budget Car Rentals Toronto Ltd. v. Petro-Canada Inc. ${ }^{28}$ where the Court held that a ROFR in a lease was not triggered by the sale of a large package of assets that included the ROFR encumbered property. ${ }^{29}$ The ROFR provided that it was triggered by the lessor's receipt of "a bona fide offer to purchase the lands and premises herein, which it is willing to accept. ${ }^{.30}$ It did not exempt from its application a package sale, nor did it require the lessor to allocate a purchase price to the encumbered property out of the bulk sale price."

The lessee, Budget, sought specific performance of the ROFR or damages in the alternative. A declaratory application was dismissed in the first instance and the dismissal was upheld on appeal. ${ }^{32}$ The underlying reasoning of both the trial and appellate courts was the same. The trial court commented as follows:

In my view, the first refusal was not triggered by the sale on the basis of the plain meaning of the clause to which I have referred. It appears to me the transaction was a sale of all assets and the undertakings owned

" Flannigan, supra note 2 at 32. This view also informed his analysis of the non-cash consideration scenario (ibid. at 12).

:s (1989), 69 O.R. (2d) 289 (C.A.)|Budger].

$\therefore$ Budget was the lessec of a parecl of land that was used in conjunction with a service station owned by the lessor, Gulf. Gulf entered into an agreement with Petro-Canada whereby the latter was to purchase all of Gulf's marketing and refinery business in Canada west of Quebec for a purchase price of \$311 million in cash plus the assumption of liabilities.

30 Budget, supra note 28 at para. 2.

31 In this regard, the clause is unremarkable in that it was very similar to the form of clause regularly used in the oil and gas industry. It is also to be noted that there was evidence before the trial court that, for the purposes of payment of sales tax and land transfer tax on the conveyed propertics, the subject property was assigned a net book value of $\$ 39,698.86$. In addition, there was evidence that at the time of the transaction the market value of the property was approximately $\$ 500,000$ and, as of the date of trial, the market value was approximately $\$ 735.000$. Thus, there was evidence that would have allowed the Court in Budget to tix a "fair market value" of the property if it was so inclined to follow the approach subsequently suggested by Professor Flannigan.

:2 As the decision may be confined to its facts, it should be noted that the Court of Appeal made particular note of the following: the purchase was extremely complex and required massive documentation that made no mention of any particular property except for some very large assets; only the very large assets received an assigned valuc; and the leased property was only one of hundreds of parcels of real property sold. 
by Gulf west of Quebec. If was in essence a purchase of Gull's husiness in that territory. P.C.I. [PetroCanada] merely stepped into Gull's shoes. There was, in my vicw, no "bona lide offer" to purchase, in those words were used between the parties. In addition, there was no offer which could have been shown to Budget, and no offer referring to the leased projects which Budgel could have matched within the five-day period stipulated in the first refusal. ${ }^{33}$

On appeal, the Court agreed that it would strain the plain language of the ROFR to oblige Gulf to break down the bulk purchase price and assign an appropriate asset price to the leased premises. The Court stated:

The acquisition of a business on the scale of Gulf s western enterprise through the purchase of assets is not done on some arithmetical basis wherein the parties negotiate a price for each individual asset and then add them up and acecpt the total. Petro-Canada was buying the retail gas and oil distribution system of Gulf as a going concem. The site which is subject to the lease in question would not have influenced the total purchase price significantly, if at all. I agree with Mr. Justice O'Brien that there was no bona fide olfer for the purchase of the lands and premises in question and, accordingly. no obligation on the part of Gulf (t) formulate an offer and present it to Budget. ${ }^{3+}$

At one level, the courts applied a technical analysis of the ROFR language in holding that it had not been triggered. ${ }^{35}$ Al another level, however, their reasoning is reflective of a broader purposive approach to the interpretation of the ROFR and the view that the transaction did not fall within the reasonable contemplation of the parties as one to which the ROFR would apply. ${ }^{36}$ This is particularly reflected by the lower court's comment that the transaction was "a purchase of Gull's business" and the Ontario Court of Appeal's comment that "Petro-Canada was buying the retail gas and oil distribution system of Gulf as a going concern." 37 Stated another way, the courts viewed the transaction as the disposition of an enterprise as opposed to the disposition of assets.

Budget can be interpreted in three different fashions. It may be reflective of a broad package sale exception based on a strict interpretive approach to the ROFR language that gives pre-eminence to an owner's rights (or, in other words, clear and unambiguous language at 262 (Ont. H.C.J.).

3" The Court of Appeal held that Gulf had no document in its hands that met the requirements and the clause because "(t)he language is clear and unambiguous that the right of first refusal applied only to a specific offer with an ascribed price for the particular piece of property that is the subject of the lease" (ibid. at para. 19). The obvious difficulty with this technical interpretive approach is that it can be used equally to assert the opposite proposition - that is, the clause clearly applied as the "lands and premises" were to be sold pursuant to the Petro-Canada offer and, as no exception for a package sale was stated. none should exist. This duality of "clear and unambiguous" meanings is also reflected by the contrasting decisions of the Alberta Court ol Queen's Bench in Apex, infra note 64 and Southland, infra note 51 , discussed below at page 494.

to While the lower court adopted such an analysis as support for its conclusion, the Court of Appeal indicated that given the clear wording of the ROFR it was unneecssary "to go into any of the evidence as to what the parties intended or to attempt to construe the contract on the basis of ulle reasonable expectations of the parties" (Budget, ibid, at para. 17). However, this statement is arguably inconsistent with the analysis reflected in the above quote from the majority decision. 
is required in order to restrict an owner's right of alienation). Alternatively, it may be limited to its specific facts ${ }^{38}$ or to an "enterprise exception" to the application of the ROFR. Or, in a variation of this interpretation, it may be reflective of a broader purposive analysis in which the ROFR language and circumstances are considered in the context of the reasonable expectation of the parties. ${ }^{39}$

Most commentators have criticized the result in Budget. ${ }^{* 0}$ While it has received a somewhat mixed reception in subsequent decisions, the trend would appear to be favouring the approach that, in the absence of clear language otherwise," package sales do not trigger or violate ROFRs.

In Municipal Savings, ${ }^{42}$ the Court considered, on a motion for summary judgment, whether a package sale triggered the ROFR and, if so, whether specific performance of the ROFR should be awarded. ${ }^{43}$ The Court recognized and applied a purposive approach to the interpretation of the ROFR, stating:

One must consider the reasonable expectations of the parties and what is a reasonable interpretation of the instrument granting the right... The Budget decision recognized this principle, but the facts bear little resemblance to the case at Bar, which involves a sale of only six properties at a block price. ${ }^{\text {th }}$

Although the Court appeared to distinguish Budget on its facts, it came to the same conclusion as the Budget court on the issue of whether the package sale triggered the ROFR, stating:

18 Because of the magnitude of the deal (i.e., hundreds of pareels), it was impossible to determine what portion of the overall purchase price applied to the ROl:R property. On a similar basis, in a scenario where assets that are subject to a ROFR are extremely important to the overall package and purchase price, such that their removal from the package would have a major impact on the purchase price for the total enterprise, it is arguable that there is again no bona fide offer for the ROFR encumbered assets. At a minimum, Budget reflects that these are factual issues that courts prefer to address in the peculiar circumstances of each case rather than upon the application of a "default rule."

This interpretation of Budget was expressed by the Ontario court in the subsequent case of Municipal Savings \& Loan Corp. v. Oswenda Investments Lid. (1989), 69 O.R. (2d) 521 (H.C.J.) [Municipal Savings].

41) See Flannigan, supra note 2 at 34; Johnson \& Stanford, supra note 2 at 339; Beck \& Mills, stupra note 2 at 49; Smith \& Denstedt, supra note 2 at 73; and Howard S. Silverman, "Commercial Leases, Rights of First Refusal and Reasonable Expectations: A Case Comment on Budget Car Rentals Toronto Lud. v. Petro-Canada inc. et al." (1990), 10 R.P.R. (2d) 180. Silverman's harshest criticism, however, related to the Court's determination that the ROFR did not survive the renewal of the lease. He also noted the strong trend in the common law towards the interpretation of contracts, even those dealing with interests in land, by reference to the parties' reasonable expectations. This trend may not bear itself out in situations involving CAPL Operating Procedures as they address. in a limiled way, package sales. See the discussion below at page 494.

42 Supra note 39. The decision was rendered after the trial decision in Budget, but prior to the release of the decision of the Court of Appeal.

4) While the transaction was not as large and complex as in Beudger, in .Municipal Savings the lessor sold all of its mixed use properties, consisting of six pareels, for the total price of $\$ 2,275,000$. In this sense. there was some similarity to Budget in that it appears the lessor was disposing of a segment of its business. In addition, although there was valuation evidence before the Court that would have assisted in the fixing of a "fair market value" of the subject property for the purposes of a specific performance remedy, the Court refused to proceed down that path. 
I have concluded that no option has been crealed in the particular circumstances of this casc. Such a sale strould nol be considered an intention to sell the "optioned" portion alone. In my view, this situation was not contemplated at the time the right was granted, and it cannot have been the intention of the parties that an option should arise in these circumstances.

Moreover. one of the essential elements of an option is missing: the selling price. No means are provided by the agreement of purchase and sale or by the right of first refusal to detcrnine this price. No consensus has been reached, or is possible between the partics. The Court cannot and should nol write their option for them. ${ }^{45}$

Curiously, in spite of this finding, the Court went on to find that the vendor and purchaser had, by entering into the package sale, "effectively rendered nugatory the personal right of the plaintiff' and directed a reference for the determination of damages for such interference. It is incongruous to find, on the one hand, that it was not within the reasonable expectations of the parties that the ROFR would be triggered in the context of the package sale at hand, but to then direct that damages be paid for the interference with the ROFR right. ${ }^{47}$ The legal basis for this result is unclear and there was no substantive analysis undertaken as to how these two findings could co-exist. As a result, the decision may be suspect as authority for the proposition that a package sale violates (as opposed to triggers) a ROFR.

However, in a case initially decided immediately prior to Budget and Municipal Savings, the British Columbia Supreme Court came to the same result on different reasoning. Associated Graphics Stupplies Ltd. v. B\&L Properties Development Lud. ${ }^{18}$ also dealt with a package sale scenario in a lease context. Unfortunately, the case provides little analytical insight on the preliminary issue as to whether the ROFR was triggered by the package sale as, on the facts, the parties treated it as triggering the ROFR. However, the case is of interest from a remedies perspective.

In the unreported decision on a motion for specific performance of the ROFR, the chambers judge ruled that the vendor breached the ROFR provisions of the lease by "failing to set out or being in any position to set out a specific price and terms for the sale of [the subject property]."49 However, in refusing to grant specific performance, the Court applied the same reasoning used in Municipal Savings and rejected the submission that it "should

Ibid. at paras. 39-40. The Court went on to find that even if the ROFR had been triggered there could have been no specific performance of the ROFR on the reasoning that to grant specific performance of the leased premises for their market value would amount to rtwriting the preferential right in that it required the owner to sell to the ROFR holder for the same price for which the owner would be willing to sell to any other person, not at market valus. Ibid. at para. 44.

47 Damages were similarly awarded as a remedy for the alleged breach of a ROFR in Downown King West Development Corp. v. Massey Fenguson Industries I.td. (1993). 14 O.R. (3d) 528 (Gen. Div.), rev'd (1996), 28 O.R. (3d) 327 (C.A.), leave lo appeal to S.C.C. refused. [1996] S.C.C.A. No. 258 (QL). However, on appeal the finding of a breach of the ROFR was reversed on a number of grounds without further consideration of the "package sale" line of cascs. judgment application. The reponted decision deals only with the assessment of damages but refers to the facts and prior decision of the chambers judge relusing the application for specific performance. 
somehow write a contract between the parties, setting out the price and terms." reason, it directed a reference for the determination of damages.

More recently, on facts more akin to those in Municipal Savings than in Budget, the Alberta Court of Queen's Bench adopted and applied Budget in whole. In Southland Canada Inc. v. Zarcan Equiries Lid. ${ }^{\text {s1 }}$ the Court held that an offer to purchase a block of land did not trigger a ROFR encumbering a leased portion of the block. The lessor, Zarcan, received a bona fide offer from West fair to purchase the block of land containing the leased premises. Zarcan issued a notice to the lessee, Southland, advising of the proposed sale and indicating that there was some doubt as to whether the ROFR applied as it appeared to be limited to the "demised premises" and would not apply to an offer for the whole block. The notice requested that Southland confirm agreement with this position. Instead, Southland purported to exercise its ROFR on the whole of the block on the terms of the Westfair offer. Westfair and Zarcan took the position that the ROFR was not triggered by the Westfair offer. Southland sought to close on the ROFR and, when Zarcan refused, it commenced an action to enforce the sale pursuant to the ROFR and obtained an interim injunction restraining Zarcan from conveying the lands to Westfair. ${ }^{52}$

In brief, the Court concluded that the ROFR applied only to the leased premises, as opposed to the package, and that the Westfair offer to purchase the entire block did not trigger it. On the first point, the Court held that the wording of the ROFR was clear and unambiguous. In considering the consequences of the opposite interpretation, the Court found that such a result would amount to a severe restraint on the lessor that could not have been intended by the parties. ${ }^{53}$

As a result of this finding, ${ }^{\text {st }}$ the Court was required to deal with the "package sale" argument. On this point, the Court referred to Budget and to Professor Flannigan's article." Applying the reasoning in Budget, the Court held it was "clear and unambiguous that the right of first refusal applied only to a specific offer with an ascribed price for the parficular

Ibid.

(1999), 254 A.R. 59 (Q.B.) [Southland]. Southland leased a portion of a block of land from Zarcan. The lease described the "demised premises" in reference to a schedule that outlined the leased portion of the block of land. The leased premises were never formally subdivided from the larger block. The lease contained a ROFR in favour of Southland, which provided that if Zarcan received a bona fide offer to purchase the "demised premises" that it was prepared to accept, Southland would be granted an option to purchase the "demised premises" on similar terms and conditions.

For the injunction decisions, sec Southland Canada, Inc. v. Zarcan Equiries LId., 1998 ABQB 230, 222 A.R. 53, afPd 1998 ABCA 336, 228 A.R. 101.

Southland, supra note 51 at para. 63. The Court noted that the form of lease was used by Southland as a lessee in many shopping complexes where it leased only a small portion of the complex. The Court reasoned that the broad interpretation of "demised premises" advanced by Southland would preclude a landlord from giving a similar ROFR to any other lessee and would preclude the owner from selling an entire shopping complex without lirst offering it to Southland. The Court considered these propositions commercially unreasonable and, therefore, not within the reasonable intentions or expectations of the parties.

The Court also had to overcome the defendants* arguments that the ROFR was unenforecable and void as it would result in a subdivision without approval. The Court rejected this argument and upheld the ROF $R$ as a contractual right on the basis that "the fact that a contract turns out to be difficult to execute will not release the parties from the expressed terms" (ibid. at para. 65).

Flannigan, supra note 2. 
piece of property that is the subject of the lease." ${ }^{\text {*t6 }}$ After referring to Professor Flannigan's article, the Court stated:

It is arguable, however, in support of $B u d g e t$, that the failure to construct a ROFR to be specifically triggered by a package deal is evidence that the parties intended that only a third party offer for the specific property will trigger the ROFR. Parties to any ROFR are free to determine their rights and to construct a contract to clearly define these rights. The wording of Southland's ROFR indicates that a third party offer to purchase the demised premises triggers the right of first refusal. ${ }^{37}$

Accordingly, the Court implicitly rejected the "default rulc" proposed by Professor Flannigan.

The court in British Columbia was again called upon to deal with a ROFR in a relatively simple package sale context in $A D E S A .^{58}$ The case arose on the application of the ownervendor for a declaration that Southern had failed to exercise its ROFR. ADESA had received an offer to buy five parcels of land for $\$ 16$ million, one of which was encumbered by Southern's ROFR. No allocation of price among the parcels was made. ADESA provided a ROFR notice to Southern that could be interpreted as an offer to buy the encumbered parcel for the bulk price or an offer to buy the entire package. In either case, the Court found that the ROFR notice was invalid. Given the manner in which the case was brought before the Court, it did not have to deal with the subsidiary remedial issues. However, the Court's comments with respect to the obligations of a vendor in a package sale scenario implied that the vendor was under an obligation to allocate a value to the ROFR encumbered property. The Court stated:

ADESA cannot defeat or circumvent the Right of First Refusal to Purchase with respect to Lot 119 by deciding to sell Lot 119 as part of a package. [Southem Railway| cannot be forced to purchase the Five Lots in order to preserve its rights with respect to Lot 119 ... 10 permit ADESA to do so would contradict the express language of the Right of First Refusal to Purchase... Therefore, before ADESA makes any sale of Lot 119, either alone or as a package, it must first make an offer to sell Lot 119 to [Southern Railway] consistent with the Right of First Refusal to Purchase. 59

In coming to this conclusion, the Court did not refer to the decisions in Budget or Southland. The only ROFR/package sale authority it referred to was its carlier decision in Associated Graphics. ${ }^{60}$

so Southland, supra note 51 at para. 78, quoting Budget, supra note 28 at para. 19 [emphasis added].

s7 Southland, ibid. at para. 82.

ss ADESA, supra note 14. ADESA owned five adjacent parecls of land. Southem Railway owned rights-ofway through three of the parcels and had registered railway rights-of-way on the other two. In addition, it held a grant of a ROFR registered as a charge against ADESA's tille to one of the parcels. There was evidence before the Coun that Southem Railway negotiated the inclusion of ROFRs throughout the Fraser Valley as an integral part of its business. In addition. gisen the nature of the ROFR in this case, upon a transfer of the land the ROFR would have ceased to have any effect unless the purchaser agreed to take title subject to the ROFR. These facts may serve to distinguish the case from the typical oil and gas context in which ROFRs arise. 
More recently, in Re Bear Hills Pork Producers Lid., ${ }^{61}$ the Saskatchewan Court of Queen's Bench applied Budget and Southland in holding that a package sale of assets did not trigger a number of ROFRs on separate parcels within the package. Similar to the facts in Budget, the package sale in Bear Hills amounted to a sale of the assets as an ongoing enterprise. More particularly, the Court's reasoning reflected the fact that the enforcement of the ROFRs would have destroyed the enterprise value of the package. ${ }^{62}$ Applying the reasoning of the courts in Budget and Southland, the Court found that where a sale of a large number of assets was contemplated there was effectively no offer for the holder of the ROFR on a single parcel to accept or refuse. However, the Court also acknowledged that "a right of first refusal cannot be avoided by simply stacking together a few properties and claiming an exemption on this ground."63

Despite these movements towards a broader acceptance of the Budget approach, it was rejected very recently by the Alberta Court of Queen's Bench in a case where the Court again had the opportunity to deal with package sales and the interpretive approach to be applied to ROFRs. In Apex Corp. v. Ceco Developments L d $^{\text {(n) }}$ the Court was asked to decide whether Apex was entitled to disregard a ROFR in respect of the transfer of encumbered assets made pursuant to a corporate reorganization.

Apex and Ceco were equal parties to a joint venture agreement for land development containing a restriction on disposition that did not include an express exception for internal reorganizations, including transfers to affiliates. Apex underwent a restructuring involving a transfer of all of its assets and liabilities, including the joint venture interest, to its parent corporation, which then amalgamated with other related entities, following which the assets previously owned by Apex were transferred to a new subsidiary (Apex Two). The directors, officers, assets, liabilities, employees, management, and ultimate shareholder of Apex Two were the same as they had been for Apex. The transaction involved many more Apex properties than those it held in joint venture with $\mathrm{Ceco} .{ }^{65}$ Prior to effecting the reorganization, Apex sought from Ceco a waiver of the restrictive right. Ceco refused this request.

Apex proceeded with the reorganization without further notice to Ceco. Very soon thereafter Ceco made an offer pursuant to the buy/sell provisions of the joint venture agreement to purchase all of Apex's interest for \$1.5 million. Apex purported to accept the offer but the sale never closed. Apex sued Ceco on the buy/sell offer and Ceco, having by then learned of the reorganization, counterclaimed that its ROFR rights had been breached by not receiving an offer to sell from Apex prior to the restructuring. Apex countered by

2004 SKQB 213, 2 C.B.R. (5th) 70, supplementary reasons at 2004 SKQB 216, 2 C.B.R. (5th) 73 [Bear Hills].

The breadth of the applicability of the case is arguably restricted by the fact that it arose under Companies ' Creditors Arrangenem Act. R.S.C. 1985.c. C-36 $[C C A A]$. proceedings where the proposed transaction was the means by which the secured creditors would best realize on their securily and where "the welfare of the business ... and the avoidance of the economic dislocation which a liquidation or winding up would involve" were valid considerations operating under the CCAA (Bear Hills (Orig. Reasons), ibid. at para. 9). However, this was offered as subsidiary justification for the decision.

Bear Hills, ibid.

2005 ABQB 656, 387 A.R. 211 [Apex].

Indeed, it involved the entire Apex enterprise, the book value of which was approximately $\$ 60$ million. with the joint venture interest having a book value of approximately $\$ 1.4$ million. 
arguing, among other things, that the ROFR did not apply as the restructuring involved a disposition to an affiliate and the post-restructuring entity, although a different corporation, was in effect the same joint venture party; an internal corporate reorganization did not constitute a "sale"; and the restructuring was a package sale that, on the basis of Budget, did not trigger the "ROFR."

The Court firmly rejected Apex's argument that the ROFR had not been triggered on the basis that the transfer to an affiliate did not constitute a transfer to a third party. ${ }^{\text {th }}$ The Court. applying a strict interpretation of the clause, also held that as the parties had not included an affiliate exception, the Court would not imply one.

With respect to Apex's argument that an internal corporate reorganization did not constitute a sale within the meaning of the ROFR, although the Court noted that some United States courts have accepted that some internal transactions do not trigger ROFRs, ${ }^{67}$ it deferred to Professor Flannigan's criticism of those cases. ${ }^{68}$ In result, the Court held that parties should either negotiate an express exception or obtain a waiver of the ROFR. It concluded:

In my view it is unnecessary, unhelpful, and inappropriate to imply an exception for non-arm's length transactions into ROFRs that are otherwise silent on the issuc. It is preferable to allow the parties to niggotiate this exception if they are so inclined. No such exception was bargained for and included in the present case."

Finally, the Court rejected the submission of Apex that the ROFR had not been triggered because the joint venture interest was part of a package of assets that were involved in the reorganization. The Court considered the reasoning in Budget ${ }^{70}$ and noted there had been a

as The Court applied the reasoning of the British Columbia Supreme Court in Cominco J.Id. V: C.P. I.Id. (1988), 24 B.C.L.R. (2d) 124 (S.C.) wherein, in rejecting an argument that two similar corporations were really the same entity, Gibbs J. reasoned: "Besides setting several decades of company law at naught. that proposition, if taken literally, would no doubt cause some alarmed reaction in the business and banking communities, and probably even in the senior levels of the [defendant corporalion]" (at para. 32). The correctness of this proposition and the Apex court's conclusion on this point should be beyond question.

bi Citing, for example, Sand v. London \& Co., 121 A.2d 559 (N.J. Sup. Ct. 1956); Kroe/mke v: 7immerman. 467 P.2d 265 (Colo. Sup. Ct. 1970); and Belliveau v: $O$ 'Coin. 557 A.2d 75 (R.I. Sup. Ct. 1989).

ox Flannigan. supro nole 2 at 18 stated that in the United States jurisprudence the judges tend to assume without basis that an arm's length transaction is required to trigger the ROFR and this implied exception allows them to read in a limitation related to the purpose of the sale despite a lack of ambiguity in the contract language. Inc. v. Ingersoll 10 Mission Developmem Ltd, 2006 ABQB 231, [2006] A.J. No. 346 (QL) [Investit Financial). 
dissenting opinion in the case and that the majority decision had not been widely accepted in Canada" and had been "firmly rejected" in the United States. ${ }^{72}$ The Court concluded:

The fundamental laws of contract interpretation militate against the automatic application of an exception for package sales in all. ROFRs. If such an interpretation were adopted, I expect that it would surprise those parties who pay good consideration to either obtain such an exclusion or provide for a valuation formula. Taking a more purposive view of the issue, allowing package sales to defeat ROFRs would render the right virually meaningless by permitting any party wishing to avoid the right to simply structure the sale on a package basis.

In my view, the sale of a property that is the subject of a ROFR as pan of a package will, generally speaking, trigger the ROFR. ${ }^{73}$

Thus, the Court reasoned that if the parties fail to exempt a package sale from the application of the ROFR, no exclusion will be implied. In coming to this conclusion, the Court commented that it had applied a contractual analysis rather than the application of a "default rule" as suggested by some commentators. In result, the Court held that "[t]he intention of the parties, as unambiguously expressed in the ROFR, was not to except package sales." ${ }^{44}$ While, as quoted above, the Court referred to a purposive interpretative approach as supporting a strict reading of the language, the decision reflects little in the way of a purposive analysis and, in result, this statement was little more than conclusory in nature. ${ }^{75}$

There are several troubling aspects of the decision. First, an essential fact that appears to have escaped the Court's attention is that the restriction on disposition in issue was not a ROFR, but a right of first offer (ROFO). A ROFO typically requires a party intending to sell its interest in the encumbered property to make to the right holder, or to invite the right holder to submit, a binding offer within a certain time period. If the prospective seller and buyer cannot agree to formal terms of sale within a specified time, or if the selling party rejects the offer submitted by the right holder, then the selling party has the right to market and sell the encumbered property to a third party on terms no more favourable than the best offer submitted to, or by, the right holder.

Citing Johnson \& Stanford, supra note 2 at 339; Municipal Savings, supra nole 39; Associated Graphics, supra note 48; and ADESA, stupra note 14. As reflected in the discussion above, the suggestion that Budget was not "accepted" in these cases is an oversimplilied analysis and arguably an incorrect statement. Further, the Court made no mention of its earlier decision in Southland, nor of the Bear Hills decision.

The Court relied, in essence, entirely upon the comments of Professor Flannigan in this regard. As reflected by Daskal, supra note 4, this may be somewhat of an overstatement with respect to the manner in which United States' jurisprudence has dealt with package sales. Apex, supra note 64 at paras. 54-55 [footnotes omitted].

Ibid. at para. 57.

However, later in its judgment (when addressing a diffierent issue), the Court noted the essential principle of contractual interpretation was to determine "the intentions of the parties at the time that the contract was made" (ibid. at para. 78) and that in doing so regard will "be had to the circumstances in which the contract was created in order to inform the words used and allow the coun to arrive at a reasonable interpretation of the contract in the particular circumstances in which it was made" (ibid. at para. 79). Had the Court applied this approach in considering the ROFR trigger issues, it may have come to a different conclusion. 
In a typical ROFO scenario, the price and terms are set by the vendor at the high end of what it thinks it would be prepared to accept, as opposed to being established by a third-party offer the vendor is willing to accept (as in a typical ROFR). In other words, a ROFO, creates a price floor for the vendor. In completing a sale pursuant to the ROFO, the vendor forgoes the opportunity of achieving a higher price or better terms by going to the market. Conversely, the ROFO holder is motivated to negotiate a fair price if it desires to preserve the acquisition opportunity or pre-empt a potential sale to an unknown third party. In this sense, while it still provides the right holder with an opportunity to acquire the encumbered interest at a price satisfactory to the vendor, ${ }^{76}$ at its inception there is no prospective third party and the "blackballing purpose" that a ROFR may be intended to serve is not present.

The ROFO clause in Apex incorporated a ROFR in the event of a proposed sale to a third party on more favourable terms than had been set out in the ROFO notice. Thus, if Apex had proposed to sell the joint venture interest to a third party for less than a ROFO offer, Ceco's ROFR may have been triggered. However, as no ROFO offer had been made, the ROFR did not come into play. As a result, the case should have proceeded as an analysis of whether Apex was obliged to make a ROFO offer prior to undertaking the restructuring, rather than whether the ROFR had been triggered.

Further, and more importantly, a ROFO does not typically contain an exception for internal reorganizations or dispositions to affiliates, as it is not triggered by a transaction with a third party, but is invoked by a direct offer or invitation from the owner (usually as a precursor to going to the market). This is borne out by the language of the ROFO in Apex:

If the Non-Disposing Party chooses not to exercise its right to acquire the Disposing Pany's interests, the Disposing Purg!' shall have the right wo marke' and sell its imterest to amy other third parly, but nol on lems more favourable than oflened by the Disposing Party to the Non-Disposing Party. ${ }^{\text {"7 }}$

Not only was the nature of the clause apparently misconstrued, but the Court's outright rejection of the argument that it was not intended to be triggered by purely internal transactions seems overly technical and ignores the words emphasized in the above quote that expressly contemplate the concept of "marketing" in conjunction with the sale of the interests. The Court applied a broad interpretation of the concept of a sale so as to include a transfer to an affiliate, but gave no effect to the express reference to the concept of "marketing" the interest. It would be a stretch to conclude that the reorganization of the nature undertaken in this case falls within the concept of "market and sell its interests to any other third party" as those terms would be understood by a reasonable observer. In this light, the express language and a purposive interpretation lead to the conclusion that the affiliate transfer (or more broadly the internal reorganization) would not fall within the reasonable expectation of parties as an event that would first require compliance with the ROFO.

7 While this is akin to the "acquisition purpose" that a ROFR may serve, it is different in that the holder is given an opportunity to buy, but in a context where it is uncertain as to whether the property will be sold to a third party if it elects not to exercise the option. Thus, the acquisition purpose is somewhat diluted in comparison to a standard ROFR.

$n \quad$ Apex, supra note 64 at para. 32 [emphasis added]. 
Notwithstanding these interpretive oversights, the Court conducted its analysis of the ROFO as though it were a ROFR and, therefore, the case provides some further insight into how the Alberta courts may deal with these ROFR issues. As noted, however, in Apex the Court did not consider its earlier decision in Southland ${ }^{8}$ or the recent decision of the Saskatchewan Court of Queen's Bench in Bear Hills, ${ }^{79}$ both of which came to the opposite conclusion on the package sale issue.

The dissonance in the reasoning and results in Apex and Southland is stark. In Southland, the Court concluded a package sale was not intended to be caught by the ROFR, as package sales were not specifically identified as a trigger of the right. In Apex, on the other hand, the ROFR applied because there was no specific exception dealing with a package sale (or an affiliate transfer). In both, the courts took the view that their conclusions arose from the "clear and unambiguous" language of the clause. The difference is perhaps explained by the fact the judges appeared to undertake their analysis from opposite vantage points. In Southland, the Court analyzed the issue from the perspective of the owner's rights, requiring the restraint on alienation reflected by the ROFR to expressly address the triggering event. Conversely, in Apex the Court appeared to approach the issue from the perspective of giving effect to the ROFR holder's rights, thus requiring any exceptions to be expressly stated.

While the results may not be reconcilable, these cases reflect the courts taking a very technical approach to the interpretation of ROFR clauses. ${ }^{80}$ As demonstrated by the conflicting results in Southland and Apex, this does not lead to a greater certainty of result. Thus, if parties desire a more certain result, or at least want the court to consider more broadly the purposes for which a ROFR is included (or excepted), they must draft with greater care. As the Apex case is under appeal, the Alberta Court of Appeal may yet wade into these issues and provide some further guidance. ${ }^{\mathrm{B}}$

The cases are also reflective of the fact that the courts are not basing their decisions on the application of a "default rule." The inconsistency of result, on comparable language and factual circumstances, also suggests that a default rule is unlikely to emerge. In terms of an industry practice, Beck and Mills considered Daskal's default rule to be "consistent with the general experience and practice of oil-and-gas lawyers in Alberta, particularly in cases when the CAPL Operating Procedures govern." ${ }^{22}$ Whether or not this view is consistent with the general experience and practice of oil and gas lawyers in all cases is debatable. However, to the extent that CAPL Operating Procedures apply, it can be argued that those Procedures have expressly addressed and made provision for a limited package sale exception and that,

is Supra note 51 .

74 Supra note 61.

80 This also tends to be reflected in the analytieal approaches of the court in Chase, supra note 13 and Calcrude Oils Lid. v. Langevin Resources, 2003 ABQB 1051, 349 A.R. 353 [Calcrude].

st As is rellected in this article's discussion of the Court of Appeal's decision in Chase (C.A.), ibid, at para. 30, the Court has perhaps provided a hint as to the direction that it may take.

8: Beck \& Mills, supra note 2 at 56 . Similar sentiments were expressed by Sinith \& Denstedt, supra note 2 at 73, although they recognized that the Budget approach may be adopted in Canada or "might be restricted to instances where the transaction is so complex that allocation is not appropriate or possible." They noted that most oil and gas conveyances (at least of that day) would not fall into such a category. 
in the absence of the exception applying, a vendor is obligated to allocate a value to the encumbered assets. ${ }^{83}$

To the extent that an allocation of the bulk purchase price is required to be made, either by law or by the terms of the ROFR, the valuation of the encumbered property presents several practical problems including how value is to be determined and whether it is to be determined on a standalone basis. As previously noted, Professor Flannigan argued that value should be established at the "fair market value" of the property on a standalone basis.

This proposition was implicitly, if not expressly, rejected in Chase, ${ }^{4+}$ which involved the ROFR provisions of the 1974 CAPL Operating Procedure. Consistent with the approach reflected in the preponderance of Canadian authorities addressing difficult ROFR issues, the lower court applied a literal approach to the interpretation of the ROFR and resorted to the supposed "implied duty of good faith performance" as the means to regulate the conduct of the vendor.

Two issues arose in the case: (1) whether the "all or substantially all" package sale exception applied; and (2) if not, whether the vendor had appropriatcly allocated value to the ROFR encumbered assets. On the issue of whether the disposition fell within the package sale exception, the lower court held that even though the receivership would, as a whole, resuit in the sale of substantially all of the assets of Sunoma, the ROFR was triggered because the language of the ROFR contemplated a single transaction in which such a disposition occurred. The Court stated that express language would be required if the parties had intended the exception to apply to plural dispositions resulting in the sale of all or substantially all of the assets."

Clauses 2402(c) and (d) of the 1990 CAPL Operating Procedure, supra note 17, provide exceptions to the application of the ROFR upon a disposition of "all, or substantially all ... [of the vendor's] petroleum and natural gas rights in the province, state or territory where the joint lands are situated ... 'substantially all' means a percentage of ninety pereent $(90 \%)$ or more of the net hectares held by such party in that province, state or territory" and upon "a disposition by a party in which the net hectares being disposed of by that party in the joint lands represent less than live percent $(5 \%)$ of the tetal net hectares being disposed of by that pany pursuant to that disposition." By expressly including such a provision, it can be argued that the parties have occupied the field of packange sales exceptions in their contract and, therefore, any package sale falling outside of these staled exceptions would not be exempted from the application of the ROFR clause.

Stupra note 13. A successor in interest to a farmout agreement went into reccivership and the receiver offered for sale substantially all of its assets in ten separate parcels. Numerous assets were encumbered by a variety of ROFRs. The litigation involved one of the ten parecls in which certain assets were encumbered by theiROFR of a joint owner ("Best Pacifie"). A ROFR notice was issued to Best Pacific in respect of the proposed sale of the parcel in which a value of $\$ 1$ million was attributed to the ROFR encumbered assets (based on the purchaser's allocation of value). Best Pacilic estimated the value of the encumbered assets at $\$ 30,000$ and took the position that the purchaser (and vendor) had inllated the allocated value to discourage it from exercising its ROl:R.

ns Chase (Q.13.). ibid. at para. 18. This issue was not raised on the appeal to the Alberta Court of Appeal. It is arguable that this result, on the facts of the case, was not in accordanee with the expectations of the oil and gas industry, as in the current draft of the 2005 CAPL Operating Procedure the language has been clarified to except bona fide plural dispositions amounting to a sale of all or substantially all of the assets from the application of the ROFR. 
In dealing with the price allocation issue, the lower court noted that the $1974 \mathrm{CAPL}$ Operating Procedure did not expressly deal with the obligation of the vendor with respect to the allocation of value. By reference to Johnson and Stanford ${ }^{86}$ and Professor Flannigan, ${ }^{87}$ the Court acknowledged that the parties may have different reasons for allocating different values to an individual property. However, it held that the vendor (and apparently the purchaser) had an obligation to allocate value in good faith, but that the ROFR holder had the onus of proving this duty was breached. ${ }^{\mathrm{s}}$ The fact that the ROFR holder came up with a different valuation from the vendor/purchaser (even as significant as it was on the facts) was not sufficient to meet this burden. ${ }^{* "}$

On appeal, while the Court acknowledged that the package sale issue was not before it given the narrow questions raised on appeal, it rejected the notion that, absent bad faith, packaging a ROFR encumbered property with other interests denies the ROFR holder its rights. ${ }^{40}$ The Court indicated that to accept this proposition

would be to read a limitation into the CAPL Operaling Procedure which is not there. The CAPL Operating Procedure has been developed by the sophisticaled participants in the oil and gas industry over several decades and has been revised from time to time to reflect the industry's experiences and changing circumstances. The language of the CAPL Operating Procedure does not exclude the possibility of ROFR lands being sold as part of a package transaction. It would be inappropriate for this Court to write in such a provision, when the industry itself has not done so as part of the private ordering of its affairs. ${ }^{41}$

These comments suggest that the Alberta Court of Appeal may reject the "default rule" advanced by Professors Flannigan and Daskal"2 that, absent clear language to the contrary, package sales should always be treated as triggering a ROFR. At a minimum, however, the Court's decision reflects a recognition of, at least in the CAPL context, the owner's right to alienate its property in a manner most favourable to it and, therefore, a rejection of the proposition that ROFR encumbered property disposed of in a package sale must be valued at "fair market value" on a stand alone basis." In result, the Court of Appeal affirmed the decision of the lower court that the allocation of value was to be undertaken by the vendor (perhaps with the input of the purchaser) reflecting the price it considered appropriate for the

so Johnson \& Stanford, stupra motc 2 at para. 54.

*: Flannigan. stupra note 2 at 33.

ax Chase (Q.B.), supra note 13 at para. 34.

Ibid. at para. 38 .

(n) This argument, as advanced by Best Pacific, is effectively that a package sale constitutes a breach of the ROFR.

1) Chase (C.A.), supra nole 13, at para. 23. The Court of Appeal noted that "unfortunately" the clause did not anticipate the issuss that arise on a package sale (at para. 17). In this regard, the dralt 2005 CAPL Operating Procedure proposes to fill this gap by expressly stipulating that in a package sale situation. unless otherwise excepted, the disposing party is obliged to provide a bona fide allocation of value to the encumbered asiets and, in the event of a disagreement as to the value allocation. the matter is to be resolved in accordance with the dispute resolution provisions of the CAPL. Operating Procedure.

v: Sec Flannigan, supra note 2 and Daskal, supra note 4.

* Chase (C.A.), stupro note 13 at paras. 19-22. The Coun acknowledged that the purchaser of a package of lands may be willing to pay more than it would have paid for a single pareel due to value enhancing aspects of a package, but also recognized the concem that the vendor and proposed purchascr may allocate value to the ROFR lands in such a way as to discourage the holder of the ROFR from cxencising its rights. 
encumbered property. If the ROFR holder considers the value allocation unreasonable, it has the burden of proving the allocation breached the vendor's obligation of "good faith."

On a broader basis, the Court appears to have accorded significant weight to the owner's right of alienation. Stated differently, it was not inclined to read a limitation on the owner's rights into the ROFR provision (particularly in the CAPL context) that was not otherwise expressed. This is more consistent with the interpretive approach taken in Birdget. Trimoc. ${ }^{44}$ and Southland than that in $A p e x$.

An aspect of the "allocation dilemma" that has not been judicially considered in Canada. but a difficulty hinted at in the courts' reasoning in Chase, is how to deal with synergistic benefits that attach to the whole of the package when a number of different ROFRs apply to separate assets within the package. Notionally, where synergies arise by virtue of the assets being packaged, they may be seen as accruing to each component of the package, such that it is not possible to allocate the incremental benefit among the individual components. In apparent recognition of this possibility, but without deciding the matler, the Court of $A$ ppeal stated that its decision was not to be taken as indicating that the court should take into account the possible impact that the decision on one ROFR valuc allocation dispute may have on other lands, and other ROFRs, forming part of the package. This leaves open the possibility that, in an appropriate case, it may be permissible for a vendor to allocate the value of the synergistic benefits in a manner that the sum of all allocations of value would exceed the total of the purchase price. Practically speaking, this would preclude all ROFR holders from excrcising on specific components as they would not be able to achicve the same synergistic benefits as the purchaser of the package. Whether or not this approach would be viewed as offensive to the reasonable expectations of the parties or an implied duty of good faith is, and should be, a fact-specific matter.

\section{Non-Cash Consideration}

Issues analogous to those arising in package sales also arise in transactions that include elements of non-cash consideration. Dispositions in the oil and gas industry may include

In Trimac, supra note 12, the Alberta Court of Quecn's Bench rejected the argument of the ROF $R$ holder that ROFRs should be read liberally to give effect to the ROFR holder's right. To the contrary, the Court applied the decision of Lord Greene, M.R. in Re Smith and Fawcet Limised, [1942] I Ch. 304 (C.A.) that a shareholder's "right [of alienation] is not to be cut down by unecrain language or doubtful implications. That right, if it is to be cut down, must be cut down with satislactory clarity" (al parat. 83). While the ease dealt with sharcholders' rights, it is difficult to conceive that a lesser degrec of respect would be accorded to an owner's property interest in land. In summarizing the calses argued by the ROFR holder, the Court stated they "go no further than to establish that the courts are reluclant to adopt a strict interpretation of lirst refusal clauses when the result would be lo defent the obvious purpose of the clause" (at para. 88). This language was prophetic ol the approacli subseculently adopted by the Court of Appeal in Mesa, srymo note 5 , as to whether one party, while technically within its rights, is acting in a manner which substantially nullifies the contractual objectives eontrary to the original purposess or reasonable expectations of the parties - sce the discussion in Part III.D. below. This approach is also consistent with the approach taken in Baggots Brass Beds Lta. v. Neal Leasing Imc. (1989), 4 R.P.R. (2d) 316 (Ont. Il.C.J.) [Baggots], dealing with a non-cash consideration scenario. 
various forms of non-cash consideration. ${ }^{95}$ In many circumstances the value of such consideration may be unique to the vendor or perhaps amorphous in nature. Typical oil and gas industry ROFR clauses deal with non-cash consideration situations in one of two general ways: the clause is silent with respect to the matter (or, stated in the reverse, no valuation obligation is prescribed); or the clause imposes an obligation on the vendor to ascribe a value to the non-cash consideration for the purposes of the price at which the ROFR holder would be entitled to acquire the interest. ${ }^{\%}$

There are very few cases in Canada dealing with non-cash consideration issues. The cases that do exist arguably do not reveal any trend other than that the courts will be vigilant in precluding the use of non-cash consideration as a circumvention mechanism. Relevant considerations that have come to the fore are: (1) whether the consideration is "impossible" to match or whether the ROFR holder could, with some effort, put itself in the position to match the consideration; (2) whether the inclusion of the non-cash consideration is supported by a rational business purpose; ${ }^{97}$ and (3) the general conduct of the parties and nature of the transaction.

The decision of the English Court of Appeal in Manchester Ship Canal Co. v. Manchester Racecourse $\mathrm{Co}^{9 *}$ has been generally considered the leading English common law decision on point. However, the decision is often mischaracterized as authority for the broad proposition that the vendor of ROFR encumbered property is obligated to translate into a cash equivalent value any non-cash consideration that it is prepared to accept. ${ }^{99} \mathrm{~A}$ careful reading of the decision reveals that the Court treated the clause in issue as a ROFO (but also indicated it would come to the same result in treating it as a ROFR). Further, on the facts the vendor had made an all cash offer to the holder of the ROFO/ROFR, so the issue of the requirement to do so did not arise. Properly analyzed, to the extent the Court treated the clause in issue as a ROFR, the decision arguably stands for little more than the proposition

w Such as, for example, asset swaps, the conveyanec of interests in other assets, spending or development obligations, voting agrecments, non-competition agreements, and where interests in facilities are involved the transaction may include reserves dedication, gas processing rights or obligations, or other guarantecs with respect to access to processing capacity. In this regard. even covenants that may be "matchable" do not necessarily result in equivalent consideration. This may be dependant on the counterparty"s ability to perform or could, where multiple ROFR holders exist, nesult in multiple parties laking the place of the proposed third-party purchaser, thus altering in a material way the contractual relationship the vendor is prepared to accept.

on See, e.g.. cl. 2401 of the 1990 CAPL Operating Procedure, sipru nole 17, which states in part:

In the event the consideration described in the disposition notice cannot be matched in kind and the disposition notice does not include the disposing party's bona fide estimate of the value, in cash, of such consideration, an offeree may ... request the disposing party to provide such estimate ... whereupon the disposing party shall provide sucl cstimate.... In the event of a dispute as to the reasonableness ol an estimate of the cash value of the consideration ... (he matler shall be referred to arbitration... The equivalent cash consideration delermined in such urbitration shall thereupon be decmed to be the sale price.

This would appear to be the same consideration that oflen underlies the ussessment of the reasonableness of the vendor's conduct in packaging assets for sale.

[1900] 2 Ch. 352 (Ch.D.), afrd [1901] 2 Ch. 37 (C.A.) [Manchester].

Sct, e.g., Stanford \& Johnson, supra note 2 at 341; Beck \& Mills, supra note 2 al 45; Smith \& Denstedt, supra note 2 at 74; and Flannigan, supra note 2 at 12. Flannigan, however, correclly noted that the decision does not clearly stand for the proposition that a vendor is required to make an all cash offer. 
that where a price translation is made, it must bear a fair and reasonable relationship to the value of the non-cash consideration. ${ }^{1 / 10}$

The issue of whether a cash conversion is required was directly addressed in Baggots, ${ }^{101}$ in which the Court adopted an approach based on United States jurisprudence. Akin to the reasoning in Budget and Southland, the Court held that a high standard should be imposed on the ROFR holder to meet the precise terms and conditions of the proposed transaction. It reasoned that offers that arguably leave the property owner "as well off" as does the thirdparty offer, but which vary materially from it, render the purported acceptance a counteroffer ${ }^{102}$ and adopted the reasoning of the Court of Appeal of Washington in Matson v. Emory: ${ }^{103}$

Allowing a cash offer to be the equivalent of the property exchange offer, regardless of the facmat sinuation, imposes a different contract on the partics and seriously inlringes on the owner's right to dispose of the property. ${ }^{104}$

The emphasized words of this quote arguably reflect a view that the courts ought not to, or cannot, develop a "default rule" that non-cash consideration must be translated into a cash equivalent. Rather, the facts and circumstances of each case must be assessed to determine whether or not the inclusion of non-cash consideration is reasonable. "1"s In this regard, the Court accepted the vendor's position that the property tendered as non-cash consideration was of particular strategic value to it and that it would not have accepted the offer at the total cash price stated if the property had not formed part of the consideration. ${ }^{106}$

As reflected by Buggols, strong arguments exist that non-cash consideration having strategic value to the vendor should not lightly be ignored. In many complex transactions (either of a package nature or where non-cash consideration forms part of the deal, or both),

The decision of the lower coun, however, rellecied a view that the vendor could not propose to enter into a transaction that would render it impossible for the ROFR holder lo exercise its rights. Sec .Hanchester (Ch.D.), supra note 98 at 365-66. This view received favourable comment in Land!more v. Hard! (1991), 110 N.S.R. (2d) 2 (S.C.). Silpra nole 94.

This rejects the approach of wome authors who have argued in lavour of a more liberal approach that it should be sufficient for the ROFR holder to purchase on terms and conditions that vary from those agreed to by the third party provided they do not vary matcrially and as long as the vendor is as well olt as it weuld have been in the third-party offer. Sec e.g., Sellingsloh, steros nolt: 12 al 41 .

676 P.2d 1029 (Wash. C. App. 1984) [.1/atson].

Baggors, supra note 94 at para. 14 [emphasis added].

Although somewhat critical of the uncertainty that Baggors creates as to what the "default nule" might be in Canada, in an insighiful comment Flannigan, supra note 2, conceded that "[t]here are plausible arguments supporting both positions" and that "[t]he issue appears to depend. in large part, on onc's view of the sufficiency of the good faith/reasonable justilication concept to regulate the mischief of manipulating the consideration to defeat the right of first relusal" (at 1 3. including $n$. 59). (iiven the prevalence with which courts in Canada have applied this approach to resolve ROFR issues, and that it allow's the coun to undertake a purposive analysis of the contract in issue, it would appear that Canadian courts are more likely to continuc down this contract/situation specific path than the articulation of "default nules" Io he applicd as the means to resolve diticult cases.

The Court also undertook an analysis indicating that, while it may have been diflicult, the ROFR holder could have attempted to acquire the land from the third party so as to be in a position to comply with the terms of the notice. but made no effort 10 do so. 
to allow ROFR encumbered assets to be extracted from a sale that produces or reflects strategic value at a price to be determined without consideration of the package benefits or unique nature of non-cash elements arguably leads to a commercially unreasonable result.

In result, it cannot be said that there is any strong authority in Canada that would require a vendor to state a cash equivalent value for non-cash consideration, absent a specific provision in the ROFR otherwise. Indeed, the authority would suggest the opposite while recognizing that partics' conduct will be regulated by the reasonable expectations/good faith standard. ${ }^{107}$ The decision in Baggots might imply that true impossibility to match may give rise to different considerations in favour of the ROFR holder; however, no court has clearly articulated such a test.

While it is often thought that the ROFR provisions of the CAPL Operating Procedures avoid this issue, this is not necessarily the case. Clause 2401 of the 1990 CAPL Operating Procedure speaks of consideration that "cannot be matched in kind." This begs the questions as to whether the consideration is "unmatchable," whether or not the ROFR holder has an obligation to make efforts to match the consideration and, if so, the extent of the obligation. These issues are untested. However, a strict application of the language arguably invokes an "impossibility" test. Industry practice, however, would seem to indicate that a liberal interpretation is applied such that any quasi-unique non-cash consideration ${ }^{108}$ will give rise to the vendor's obligation to state a cash equivalent price. To the extent a cash translation is required, valuation issues arise that are similar to those discussed above in the package sale context.

\section{A BRIEF NOTE ON "GOOD FaITH"}

Some Alberta courts have been more reluctant to express a broad-based implied duty of good faith in contractual performance. Indeed, in the leading Alberta authority of Mesa, ${ }^{109}$ the Court of Appeal expressed concern that the concept would cause a blurring of the distinction between the "two sources of rules about contracts, the law and the contract": 110

Sometimes a rule of law imposes a duty or a constraint upon the parties to a contract despite their agreement, as is the case of the rules about illegal contracts and unconscionable contracts. On other occasions, however, the courts impose a rule upon the parlies because we conclude that this fulfils the agreement. In other words,

The U.S. authority relied upon in Baggots, supra note 94, is to the same effect. In Matson, supra note 103, the Washington Court of Appeal concluded at 1032 that it would take a "middle course," stating: "By implying a duty of reasonableness and good faith in property exchange offers we adopt a course which protects the interests of both the property owner and the holder of the right." In clear recognition that the issue concemed the competition between the property owner's right of alienation and the restraint on alienation imposed by the ROFR, the Court stated at 1033 that "[a]bsent findings of bad lat h or unreusonableness, the property owner should retain primary control over disposition of the property." By this we mean consideration such as other property, interests, or rights that are not presently possessed by and cannol be conveyed by the ROFR holder. as opposed to contractual obligations or covenants that would be capable of heing granted.

110 lbid. at para. 15. 
the duty arises as a malter of interpretation of the agrememt. The source of the rule is not the law but the partics. ${ }^{111}$

On the facts of the case, the Court determined that the contract created certain expectations between the parties and that these expectations were reasonable and should be enforced.

This approach is less a matter of assessing whether a party is acting in "good faith" or "bad faith," but whether a party is performing its contractual obligations in a way that does not "substantially [nullify] the contractual objectives or [cause] significant harm" to the other party. "' Applying this approach in a ROFR context, the court is to discern the contractual objectives, purposes, and expectations of the parties reflected in the language and surrounding circumstances and then examine whether the reasonable expectations of the parties are being met or thwarted by the transaction in issue. ${ }^{113}$

The most frequently cited example of the application of the "good faith" duty in a ROFR context is the decision of the Ontario Superior Court in GATX Corp. v. Hawker Siddeley Canada Inc. ${ }^{114}$ While generally cited for the Court's broad statement that "[i]t is well established that the grantor of a right of first refusal must act reasonably and in good faith in relation to that right, and must not act in a fashion designed to eviscerate the very right which has been given," 11 's the application of the case is arguably limited by the fact that the defendant admitted the corporate reorganization undertaken was carefully and purposely structured in such a way as to avoid the plaintiff's ROFR. ${ }^{116}$ The Court determined that "the proposed transaction cannot be subdivided into isolated parts - each of which, if considered out of context, might appear individually to be benign - and given effect to on that basis, given the existence of the Right of First Refusal which clearly attaches if the transaction is viewed as a whole."11?

Ibid. [emphasis omitled].

112 Or, as more recently explained by Topolniski J. in National Courier Senvices LAd. 1. RIJK HIbdraulic Cylinder Services Inc., 2005 ABOB 856, 390 A.R. 158 at paras. 29. 31-32: "Mesa was not decided on good or bad laith printiples as the court found the answer lay in the contract itself and the reasonable expectations it created about its meaning and perlomance standards, having regard to the commercial context. in my view, the law in Alberta does not yet reeognize a general duty of good faith in the performance of a contracl."

11. Put in this conlext, enforcing "good faith" performance is nothing more than interpreting and applying the contractual language in a manner that promoles or advances the intention of the parties or the intcrpretation that produces the most reasonable result or, as stated by Estey J. in Consolidated-Bathurst Export Limited v. Mutual Boiler and Machinery Insurance Company, [1980] I S.C.R. 888 at para. 26, "the normal nules of construction lead a court in search for an interpretation which, from the whole of the contract, would appear to promote or advance the true intent of the parties at the time of entry into the contract." Consequently, where the words used in the contraet inay bear two constructions, "the more reasonable onc, that which produces a fair result, must corlainly be taken as the interpretation which would promote the intention of the parties" (ibid.). (1996), I O.T.C. 322 (Gien. Div.)|(iATR].

IIs Ibid. al para. 73.

The converse argument would be that where there are legitimate business reasons for a particular structure for a transaction. the court should not interlere if a collateral effect of the structure is that a ROFR is not triggered but might have been triggered under a diflerent transaction structure. 
If $G A T X$ is to be applied beyond its narrow facts, it is diflicult to square with the decision in Trimac ${ }^{\prime 18}$ where the Court allowed an owner to organize its affairs and structure a transaction in such a way that it would not trigger the ROFR clause in a unanimous shareholder agreement. In Trimac the Court strictly construed the ROFR clause and, after reviewing various Canadian cases on ROFRs, held that each case turned on its own peculiar facts. In result, the Court allowed an owner to organize its affairs in such a way as to avoid triggering a ROFR clause. However, the Court frequently noted that the vendor's purpose in structuring the transaction was to achieve the highest price possible for its shares and, in so doing, was endeavouring to avail itself of a buy/sell provision in the unanimous shareholders' agreement, as opposed to triggering the ROFR. Thus, Trimac can be viewed as a case where the vendor's efforts, although structured to avoid triggering a ROFR, were justifiable and supported by legitimate business purposes.

The GATX case, considered in the context of the purposive interpretation approach reflected by the Court of Appeal's comments in Mesa, is merely reflective of one side of the same coin. That is, not only should the reasonable expectations of the ROFR holder not be defeated by the strict application of the contract language, but the same protection ought to be afforded the reasonable expectations of the owner-vendor. This approach would require the court, in either circumstance, to look beyond the strict language of the clause and consider its purpose and the effect of the transaction. ${ }^{119}$ Applying this approach to Apex, ${ }^{120}$ for example, instead of simply finding that each technical component of the ROFR clause applied to the transaction - i.e., that it was a "sale" to a "third party" without an affiliate exception - as in GATX, the Court should then have considered the effect of the application of this strict interpretation (the triggering of the ROFR) in the context of the reasonable expectations of the parties. In other words, if this approach is to be used to deny a vendor the ability to structure its affairs in technical compliance with a contract so as to avoid a ROFR, so too should it be available to a vendor where, on a narrow technical application of the language, the transaction may be seen to trigger a ROFR. The court's function in this regard would be greatly assisted by more attention being paid by the parties to an expression of the purpose for which the clause is included or a clearer articulation of the intended result in scenarios giving rise to these interpretive difficulties.

\section{E. Remedies}

The remedies available for breach of a restriction on disposition include injunctive relief, specific performance, and damages depending on the circumstances of the case. Remedial trends may be difficult to discern as in many cases the remedy granted upon a finding of breach is highly fact dependent. The following provides a synopsis of the relevant considerations that factor into the determination as to whether equitable relief (injunctions and specific performance) will be granted or whether the remedy for a breach of the right will be limited to damages.

\footnotetext{
11x Supra nole 12.

114 It is arguable that most, if not all, of the ROFR cases that have found in favour of the owner can be rationalized on the basis of this principle. See also Ama Resources Lrd. v. Boliden I'esimin L.th., [1998] B.C.J. No. 3179 (S.C.) (QL). 
Two factors have historically supported the granting of equitable reliel' lor the breach of a ROFR: ${ }^{121}$ (1) a ROFR is a negative covenant; ${ }^{122}$ and (2) in some jurisdictions it is an interest in land. ${ }^{123}$ Traditionally the equitable, discretionary remedy of specific performance was available where it could be established that an award of damages was an inadequate remedy. This usually involved showing that the subject matter of the contract was so unique that money could not compensate for its loss. In the case of property it was long presumed that there could be no adequate replacement and so specific performance was the appropriate remedy. ${ }^{124}$ The decision of the Supreme Court of Canada in Semelhago v. Paramadevan ${ }^{135}$ effectively rejected the notion that specific performance is the presumptive remedy for breaches of contract in cases dealing with real property. ${ }^{126}$ Broadly speaking, the rationale underlying this rejection was that in the world of modern commerce, property is often as fungible a commodity as consumer products. While the Semelhago case dealt with residential property, the rationale arguably applies to mineral interesis, which in many cases are replaceable economic interests. ${ }^{127}$ Thus, depending on the nature of the subject matter of the ROFR, it could be argued that the interest is not unique and could be replaced by other similar assets. Subject to consideration of the "negative covenant" aspect of ROFRs, and combining this rationale with the theory of efficient breach discussed below, it may be that damages rather than specific performance could become the preferred remedy, particularly in situations where difficult valuation issues arise in determining the basis upon which a right would be specifically performed. In such circumstances, the obligation to mitigate would become an even more important factor for parties to assess. ${ }^{12 k}$

121 The first also applies to most other forms of restrictions on disposition. It is arguable that a ROJ:O with a second stage ROFR would also constilute an interest in land willin the application of the law of Property Act, supra note 9, s. 63.

12. Cancitian Long Island, stupra note 8.

123 See stupra note 9.

124 Donald H. Clark, "Will that be Performance ... or Cash?": Semedhogo v. Parmodevan and the Notion of Equivalence" (1999) 37 Alta L. Rev. 589 at 591.

12. [1996] 2 S.C.R. 415 [Semelhago].

12\% Ibid. at para. 21 where Sopinka J. held: "It is no longer appropriate, therefort, lo maintain a distinction in the approach to specific performance as belween realty and personalty. It canmot be assumed that damages for breach of contract lor the purchase and sale of real estate will be an inadequate remedly in all cascs."

In this regard, see Consfellation Oil \& Gas /kd. v. Sumoma Energv Corp. (1999), 252 A.R. I77 (Q.B.) where the Court denied the injunction application of onc prospective purchaser secking to restrain the sale of certain mineral interest and tangible property to a third party. The Court held that the assets were not unique to the plaintiff and, therefore, it could not meet the irreparable harm test. The Court made this finding even where the plaintiff had made other acquisitions and entered into other contractual commitments in anticipation of closing the acquisition of the subject assets. In this context. to the extent a ROFR is included to serve a "blackballing purpose" as opposed to the "acquisition purpose," it is arguable that a stronger rationale for a strict enforcement of a ROFR exists. An acquisition purpose is more likely to be seen as a pure economic purpose that can be accommodaled by an economic assessment of the damages suffered where it is not honoured. On the oflec hand, the "blackballing purpose" may imply considerations unique to the ROFR holder and the proposed third party that may not be as capable of economic assessment.

128 If specific performance is not the presumed remedy, then the non-defaulting party will be expected to mitigate their losses. See, e.g., Asamera Oil Corp. v. Sea Oil \& Ge'meral Corp., [1979] 1 S.C.R. 633; Calcrude, supra note 80; and Associated Gruphics, supra note 48. 
Where the breach of a negative covenant is involved, the usual criteria for injunctive relief $^{124}$ have been applied less stringently in Alberta. The Alberta Court of Appeal has suggested that if there is "a clear breach of a clear covenant," such as a negative covenant, then an injunction could be granted without showing irreparable harm. ${ }^{130}$ While this approach has gained general acceptance in Alberta, in many cases the issue whether a ROFR is triggered or violated is a difficult one that will render it unlikely a ROFR holder would be able to avail itself of the less stringent test in seeking an injunction. ${ }^{131}$

Where the less stringent test does apply, courts have struggled somewhat with the application of the balance of convenience test. As the balance of convenience is also a factor considered in assessing whether specific performance should be granted, the Court of Appeal's comments are worthy of note in that context as well. In both Debra's Hotel ${ }^{132}$ and ExronMobil, ${ }^{133}$ the Courts stated that the balance of convenience cannot be said to favour a party in breach of the covenant. It is arguable, however, that this view overlooks the purpose of assessing whether equitable relief (be it an injunction or specific performance) should be granted for a breach of contract. Generally speaking, the presumptive relief for breach of contract lies in damages. While other factors, such as the breach of a negative covenant, may lend support to the granting of equitable relief, the court is not excused from considering the balance of convenience. ${ }^{134}$

In this regard, a consideration that may come into play in some cases, but is often overlooked by the parties and the court, is the theory of efficient breach. This concept derives from postmodem law and economics theory and states that "where the plaintiff's expectation interests arising from a breach of contract can be met by an award of damages, it is economically efficient to permit defendants to breach their contracts with a view to

129 The traditional test for the granting of an injunction is the tripartite test set out by the Supreme Court of Canada in RJR-AkacDonald : The Allorney General of Canada, [1994] I S.C.R. 31 I: (i) whether there is a serious issue to be tried?: (ii) whether the plaintifl would sufter irreparable harm if an injunction is refused; and (iii) whether the balance of convenience, having regard to all the factors, would favour the granting of an injunction.

In a line of cases exemplified by Canada Safeway Lfd. v. Excelsior life Insurance Co. (1987), 82 A.R. 316 (C.A.) and M/CDonald's Restauramis of Canada L.d. V. West Edmomton Mall Lid. (1993). 141 A.R. 266 (C.A.). This approach was explained in detail in the decision of Debra's /lote/s /nc. v. Lee (1994), 159 A.R. 268 (Q.B.) [Debra's Hotel], where the Court held that the latter two prongs of the test could be applied less vigorously when there has been a clear breach of a negative covenant. However, while the Court was prepared to dispense with the irreparable harm test, it was not prepared in ignore an examination of damages (which would usually be dealt with under irreparable harm), nor the balance of convenience. This approach was also applied in Exron.Mobil Canada Energr 1 : Novagas Canada Lid., 2002 ABQB 455,381 A.R. 99 [Ex.ron.Mobil], where ExxonMobil conceded that it could not demonstrate irreparable harm and. therefore, the tripartite test could not have been satisfied absent this finding. Sec Southlend, supra note 51 and CIBC Developmen Corp. v. 724/33 Alhersu LAd., [1999) A.J. No. 1656 (Q.B.) (QL).

13: Debra's Hotel, supra note 130.

13. ExronMobil, supra note 130.

13. See, e.g., Sekhon v. Armstrong, 2003 BCCA 362, [2003] B.C.J. No. 1552 (QL). In this case the Court also stated that a "negative covenant is less likely to be enforced on an interim basis than at trial" (at para. 22). 
increasing their own profits."135 The theory was given somewhat vague approval by the Supreme Court of Canada in Bank of America Camada v. Murual Trust Co. ${ }^{136}$

Applying this theory to a ROFR situation, it could be argued that an owner should be allowed to breach a ROFR where the breach could be adequately compensated in damages, particularly where the inconvenience or cost (or loss of opportunity) to the owner arising from compelling performance would outweigh the damages suffered by the ROFR holder.

While it is difficult to predict with any certainty the remedy that would be imposed in a given ROFR case, it is clear that parties are exposed to considerable financial risk depending on which route they take. If an owner (or third-party purchaser with notice) takes the view that the ROFR is not triggered and does not make an offer to the ROFR holder, they are at risk of having their transaction held up and potentially frustrated by the imposition of an injunction. They are also at some risk that an order for specific performance would be granted. $^{137}$

On the other side of the equation, a ROFR holder who asserts its rights by seeking an injunction will likely have to give an undertaking or other security. If it turns out that the injunction was improperly granted ${ }^{138}$ the ROFR holder has exposed itself to a potentially significant damages claim if its actions interfered with or delayed a large and complex transaction.

\section{SPECIFIC TRANSACTIONS OF INTEREST}

As the Western Canadian Sedimentary Basin has matured, the need for economic efficiency has become a primary driver for oil and gas companies. As a corporation may not be the most tax effective way of ordering affairs, the use of partnerships and trusts, driven largely by opportunities for tax advantage, has become commonplace.

13. Evergreen Building Lid. v. IBI Leaseholds LId., 2005 BCCA 583. 50 B.C.L.R. (4th) 250 at para. I4. leave to appeal to S.C.C. requested, [2006] S.C.C.A. No. 43 (QL) [Evergreen]. See also lan R. Macneil. "Eflicient Breach of Contract: Circles in the Sky" (1982) 68 Va. L. Rev. 947.

2002 SCC 43. [2002] 2 S.C.R. (00)] [Bank of America] where, at para. 31, in addressing the matter of "restitution damages" in contract cases (an award of damages reflecting the disgorgement of the defendant's profits as opposed to the plaintifrs expectation damages), the Court stated:

Courts generally avoid this measure of damages so as not to discourage efficient breach (i.c.. where the plaintiff is fully compensated and the defendant is better off than if he or she had performed the contract).... Efficient breach is what economists describe as a Pareto optimal outcome where one party may be better off but no onc is worse off, or expressed differently. nobody loses. Efficient breach should not be discouraged by the courts. This lack of disapproval emphasizes that a court will usually award money damages for breach of contract equal to the value of the bargain to the plaintiff.

It should also be noted that orders for specific performance can be accompanied by damage awards if

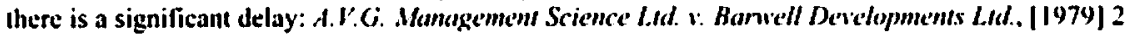
S.C.R. 43; Ian'-Woman Managemen Corp. v. Regional Municipality of /'ed (1991), 2 O.R. (3d) 567 (Gen. Div.). In addition, damaes awards can inclucle, in an appropriate case, the value of other opportunities the ROFR holder may have lost by virtue of not having been able to acquire the property: see Associased Graphics, supra note 48 and the damages assessment in Apex, supra note 64. As was the end result in Southland, supra note 51 . 
Whether a ROFR is triggered upon the contribution of assets to a partnership or a conversion to a trust will again depend largely on the language of the governing document and the structure of the transaction. However, these types of conversions and transactions are traps for the unwary. The language of the governing document is occasionally restrictive enough, or the structure of the transaction is such, that ROFRs may be triggered, in which event the consequences could be significant.

\section{A. Partinersilip Contributions}

A partnership does not enjoy a separate legal existence from its partners and, therefore, the contribution of assets to a partnership involves the creation of a pool of partnership assets that are owned jointly, and held in trust, by all of the partners for the benefit of the partnership. ${ }^{139}$ Applying this principle, the effect of a contribution is to transfer an interest in the contributed assets to each partner commensurate with their respective partnership interest. Accordingly, in the absence of an applicable exception (such as for translers to affiliates or to a partnership in which the transferor obtains a partnership interest), ROFRs are likely to be triggered upon the contribution of assets to a partnership. ${ }^{1.0}$ It is conceivable that structures can be put in place in the creation of a partnership, or in the dedication of assets to the partnership, that could avoid the triggering of ROFRs. However, such structures would be open to challenge as defeating the reasonable expectations of the parties on the basis of Mesa ${ }^{1+1}$ or GATX. ${ }^{1+2}$

The 1981 and 1990 CAPL Operating Procedures contain a specific exception for dispositions to partnerships in return for an interest in the partnership. This exception would appear to apply so as to preclude a ROFR from being triggered when a partnership is created by arm's length non-affiliated parties, as the affiliate exception in the CAPL would otherwise apply where the partnership is comprised of affiliates. The draft 2005 CAPL Operating Procedure proposes to delete this partnership contribution exception, presumably on the basis that the CAPL ROFR should be triggered by such contributions unless the affiliate exception applies.

\section{B. Trust Conversions}

There are variations to the trust structure that a corporation may employ depending on the circumstances. In addition to the basic conversion from corporation to trust, a more complex form of conversion, and one frequently used in the oil and gas industry, is where the assets of the pre-conversion corporation are divided in order to create a trust and a separate exploration corporation.

Trust conversions and their potential interplay with ROFRs or other restrictions on disposition have garnered little or no attention in the literature or case law. This may simply be reflective of a permissive attitude in an industry that acknowledges the benefits of trust

\footnotetext{
Ito Boyd : British Columbia (A.G.) (1916), 54 S.C.R. 532 at 553.

1to This conclusion is also supported by the result and reasoning of the Alberta Court of Queen's Bench in Calcrude, supra nole 80.

Supra nole 5.

Supra nole 114.
} 
conversions and how pervasive they have become. However, three factors may lead to industry participants that are holders of restrictive rights (which increasingly includes other energy (rusts) taking a more aggressive stance in enforcing the rights, particularly where it may provide the opportunity to acquire additional interests in mineral reserves of strategic value. First, as producible reserves are the lifeblood of energy trusts, ${ }^{143}$ it is reasonable to anticipate that the continuing maturation of the Western Canadian Sedimentary Basin may create circumstances where available (or preferred) land acquisition options become more scarce. The second is the apparent proclivity of the Alberta courts to take a technical approach to the interpretation of ROFRs where the industry's permissive approach to transactions may not be supported by a strict application of the language of contracts. Third, as the establishment of a trust may result, directly or indirectly, in a separation of the legal and beneficial interests in the underlying assets, on the reasoning of the Alberta Court of Queen's Bench decision in Calcrude, ${ }^{144}$ that separation may trigger ROFRs in the absence of other applicable exceptions.

As a result. parties undertaking trust conversions need to consider carefully the potential implications of the conversion on ROFRs and other restrictions on disposition that may thereby be triggered. In doing so, it is necessary to understand the basic structure of the common forms of conversions.

\section{BASIC CONVERSION: CORPORATION TO TRUST}

The simplest form of income trust conversion is one where a trust is imposed as the controlling sharcholder of an operating corporation that conlinues to own all of the assets of the business. In the process of conversion the sharcholders of the original operating entity become unitholders of the trust and the operating entity amalgamates with a subsidiary of the trust that is indebted to it (the TrustCo). In the usual case, legal and beneficial title to the assets remain with the TrustCo. Thus, in the absence of a beneficial interest in the assets being conveyed outside of this typical form, or in the absence of an argument that the structure indirectly creates a separation of legal and beneficial interests, this type of conversion would not trigger most industry-standard ROFRs since it involves a change in

The structure of a trust is such that it must continually replace declining reserves with new production in order to maintain its distributions. Typically. trusts do not expend signilicant investment in exploratory endeavours, favouring instead the acquisition and development of proven and probable reserves.

14t Supra nole 80. One of the issues the Court addressed was whether a vendor is entitled to distegard a ROFR in respect of the disposition of a beneticial interest to an undiselosecl party where the owner continues to hold the legal interest. In this ease the subject lands were govemed by a farmout agreement that incorporiled the 1974 CAPL ROIR. In a series of transactions, one working interest owner conveyed bentelicial interests in its working interests to a "silent partner" for which no ROFR notices were issued. When the silent partner conveyed its benelicial interest to a third party the other working interest owners claimed for a breach of their ROFR rights on the initial transfers of the heneficial interests to the silent partner. The Court held that the transfers of the beneficial interests were distinet transactions that triggered the ROFR. The Court. referring to GATX, noled that in all of the circumstances the fact the dispositions were never disclosed to the other working interest owners implied that they were done to circums snt the ROFR. 
control of the shares as opposed to a transfer of assets. Changes in control are generally not treated as triggering events in typical restrictions on disposition. ${ }^{145}$

\section{COMPLEX CONVERSION: CORPORATION TO TRUST AND EXPLORATION CORPORATION}

As many energy companies hold both lower risk, established, producing properties and higher risk, exploratory properties, the basic income trust conversion is often modified so that the benefits of each asset class are maximized. In this situation a more complicated form of trust conversion occurs that results in the TrustCo retaining ownership of the established producing asscts, and the incorporation of (or amalgamation with) an exploration corporation (the ExploreCo) that owns the more speculative exploration assets. This type of conversion may occur in the context of a business combination where the assets of two entities are split in conjunction with a merger. Typically, the converting entity conveys the exploration assets directly to the ExploreCo and, if the ExploreCo does not meet the definition of affiliate at the time of the transfer, ${ }^{146}$ or if the ROFR does not contain another applicable exception, this disposition to the new entity will trigger the ROFR. ${ }^{147}$ The issues are further complicated by virtue of the fact that court approval of trust conversions is commonly obtained pursuant to the arrangement provisions of applicable business corporations legislation. ${ }^{1+8}$

\section{Pl.ANS OF ARRANGEMENT}

Court approval of a plan of arrangement involves the granting of an Interim Order allowing the company to present the plan to its shareholders, a shareholder vote, and a Final Order approving the plan's implementation. The only persons that the legislation specifically contemplates receiving notice of and voting on the proposed arrangement are the shareholders of the corporation and, if the court considers them to be affected by the proposed arrangement, its creditors. ${ }^{199}$ The corporation's contractual counterparties do not receive notice. If granted, a Final Order "is binding on the corporation and all other persons." 150

Sec, e.g., Glimmer Resources Ihc. v. Exall Resources I.rd. (1997), 39 O.T.C. 215 (Gen. Div.) and Ke'mucky fried Chicken Canoda v. Scoll's Food Services Inc. (1998), 4 I B.L.R. (2d) 42 (Ont. C.A.). This would be the case unless, on the basis of the reasoning in CATX, supra note 114, llie evidenee indicales that the structure is being used for the purpose of frustrating or avoiding a ROl'R right. $O r$, if it subsequently ceases to be an afliliate (as is usually the case), the application of a $G A T X$ analysis could lead to the transaction being challenged on the basis that it amounted to an indirect transfer without complying with the ROFR.

The existing CAPL Operating Procedures do not contain an exception for "arrangements" and one is not presently contemplated in the draf 2005 CAPL Operating Procedure. An argument could be made that the "all or substantially all of the assets" exception may apply (see, e.g. cl. 2402(c) of the 1990 CAPL Operating Procedure, supra note 17), however, on the Court's reasoning in Chase (Q.B.), supra note 13 at para. 18. if the disposition of all of the assets is made to two different parties the exception does not apply.

Business Corporations AC1, R.S.A. 2000, c. B-9, s. $193[A B C A]$. Similar provisions exist in the Camada Business Corporations ACl, R.S.C. 1985, c. C-44, and other provincial legislation. They set out a procedure through which a corporation can obtain a court order approving a restructuring. $A B C A$, ibid., s. 193(4)(a) and (b).

Isi Wid., s. 193(13). 
This raises a number of issues concerning ROFRs: Are the holders of ROFRs that may be impacted by the conversion entitled to notice?; Does the court's blessing of an arrangement render unenforceable a ROFR (or other restrictive right) that might otherwise have been triggered by the conversion?; If third-party rights survive the conversion, what risks are being taken by the plan proponent in implementing the plan without honouring those rights or, from the rightholder's perspective, what remedy would be available if it is later shown that the conversion triggered rights? There is very limiled jurisprudence in Canada dealing with these issues.

In First Choice Capital Fund Lid. v. Saskatchewan (Director of Corporations), ${ }^{151}$ the Saskatchewan Court of Queen's Bench dealt with the issue of notice to affected third parties and the impact of an approved arrangement on third-party rights. The Court held that the third party was entitled to and should have been given notice of the application for approval of the arrangement and, without it, its rights could not be affected by the granting of the Final Order approving the arrangement. ${ }^{152}$ This decision would impose a positive obligation on the applicant in a trust conversion arrangement, especially one that involves a business combination, to give notice to the ROFR holder of the arrangement and the opportunity to appear at the application for the Final Order, the absence of which could result in the arrangement being set aside. This would constitute a significant departure from the current practice.

Recently in Alberta, in PetroKazakhstan Inc. v. Lukoil Overseas Kumkol B.V., ${ }^{153}$ the standing of a ROFR holder to oppose an arrangement was accepted without challenge or comment. While the Alberta Court of Queen's Bench granted the Final Order over the objections of the ROFR holder, it commented that the Order would not operate so as to extinguish the ROFR holder's rights (which it was pursuing in a separate arbitration).

PetroKazakhstan and First Choice Capilal provide strong support for the proposition that restrictive rights will not be rendered nugatory by the approval of an arrangement. First Choice Capital would impose an obligation on the applicant to give notice to right holders. PetroKazakhstan, at a minimum, implicitly acknowledged the right of a holder to appear and oppose the arrangement.

While on the facts in PetroKazakhstan the Court was not prepared to defer approval of the arrangement until the ROFR claim was decided and granted the Final Order, it did so on the specific facts before it. The Court commented that it was not inclined to allow "vague and speculative"154 assertions of harm to the third-party ROFR holder to outweigh the interests of the shareholders of the corporation, 99 percent of whom had approved the otherwise fair arrangement. The Court held that the arrangement was fair and reasonable, focusing on the

2000 SKQ13 516, 200 Sask. R. 209 [Firs/ Choice C'apilot], Deloitte, a third party whose interests were adversely alfecled by the arrangement in that ease, did not learn of the arrangement until over a year aller the Final Order was issued. and brouglt an applieation to set aside the Interim and linal Orders. While the (Court indicated that an applicant who neglects to serve the application on all adversely alfecled parties runs the risk that the order may subsequently be set aside or varied, it declined to do so in the circumstances of the case, insteikl curing the lack of notice by less disruptive means. 
benefits it derived for shareholders, and found that granting a stay of the proceedings to allow the ROFR issue to be determined would likely result in a termination of the arrangement that would prejudice the shareholders, perhaps irreparably. ${ }^{155} \mathrm{It}$ is noteworthy that in arriving at this conclusion, the Court made specific mention of the fact the arrangement would result in the shareholders receiving cash for their shares, rather than shares in any post-arrangement entity. As such, they would not be affected by any liability that the company may suffer if the ROFR holder succeeded in its claim. ${ }^{156}$ This implies that in circumstances where the prearrangement shareholders would receive shares in one or more post-arrangement entities, as in the typical trust conversion secnarios, the potential impact of liability for breach of a ROFR would be a relevant consideration as to whether the arrangement should be allowed to proceed prior to a determination of the ROFR right.

In this regard, the principal requirement that must be satisfied in order to obtain approval of an arrangement is that the plan must be "fair and reasonable." 157 If the applicant succeeds, the burden shilis to opposing parties to convince the court that they have interests that will be significantly affected by approval of the arrangement. ${ }^{15 x}$ The test to determine the fairness of a plan of arrangement is the "business judgment" test: namely, "whether the court may conclude that an intelligent and honest business person, as a member of the class concerned and acting in his or her own interest, might reasonably approve of the plan." 199

As is rellected by the decision in PetroKazakhstan, even if the rights of a ROFR holder are considered under the business judgment test, a court balancing its interests against those of the major stakeholders in the arrangement may be loath to interfere with the plan. ${ }^{160}$ Thus, even where a restrictive right holder opposes an arrangement, it remains unclear whether the court would be persuaded to award it a remedy. The broad power to approve an arrangement that is "lair and reasonable" would permit the court to override the third-party rights if satisfied that the business judgment lest is met. In this regard, the applicant for approval of a trust conversion arrangement may argue that faimess and sound business judgment dictates that the assets should be kept together as a "package" to allow for their efficient exploitation, or that the package of assets constitutes a going concem, ${ }^{161}$ such that the removal of certain

Thidl at para. 48.

lbid. all para. 53.

Re. St. I.uwrence of Hudson Railury (o. (1998), 76 O.T.C. 115 at para. 12 (Cien. Div.) [.St. Lanrence \& Hudsen Railuay]. See also Amoco Acquisition Co. v. Dome Petroleum Co. (1988), 59 Alta. L.R. (2d) 260 (C.A.).

Re. Canadian Pacific Lid. (1990), 73 O.R. (2d) 212 (H.C.J.).

Re Trieec Corp. (1994), 21 Alta. L.R. (3d) 435 at para. 31 (Q.B.). The Court also said at para. 36 that it "must be careful not to cater to the special needs of one particular group but must strive to be fair to all involved in the transaction depending on the circumstances that exist," and at para. 42 that "Parliament clearly intended that a plan of arrangement might involve a compromise on the part of all partics for the greater good of the whole." In Amoco Acquisirion Co. v. Sanuge (1988), 87 A.R. 321 (C.A.), the Court held that while it canvasses the views of several groups, the arrangement can be approved without a specific group's views, or despite them. However, it expressed these views in the conlext where it was only considering shareholder and creditor interests.

In Si. Lanrence de Imetson Ruiluca, snpra note 157, the Court stated that "a substantial vote in favour ol the proposed plan of arrangement by the security holders affected is an important factor in the court's considerations. The 'business judgmenl" of the sccurity holders in determining their own interests is to be given great weight."

Drawing, by analogy on Budget. stpra note 28 and Bear Hills, supra note 61. 
assets would defeat or undermine the legitimate objectives of the arrangement, or that the trust conversion is nothing more than an internal reorganization. ${ }^{162}$

Given the broader interests that are considered in an arrangement context, ${ }^{163}$ courts may be inclined, supported by existing authority that strictly construes restraints on alienation, to approve of the transaction in spite of the impact on the third-party rights. However, if the Alberta courts were to continue with the more recent inclination to give restrictions on disposition, and particularly ROFRs, broad effect, the opposite result could follow with the result that the trust conversion would be seen to trigger the ROFR. If specific performance was granted as a remedy, this result could materially impact the viability of the TrusiCo or the ExploreCo and could expose the directors and management of the pre-conversion entity to shareholder claims if the conversion was completed without prior notice to ROFR holders. However, the difficulties and uncertainties that may be created by an effort to unwind the arrangement in whole or in part could lead a court to the conclusion that damages would be a more appropriate remedy. Regardless, the uncertain state of the law suggests that parties considering a trust conversion without undertaking a careful assessment of whether ROFRs may be triggered, and the consequences of such an event, are undertaking a significant risk.

\section{Conclusion}

The ROFR case law dealing with complex transactions does not reflect the adoption of "default rules" as a "one-size-fits-all" approach to the resolution of difficult interpretive issues. The permutations of the issues and considerations that can arise are numerous and potentially thorny. It is hazardous for parties to presume that such issues will be resolved by, or are capable of being a idequately reflected by, the application of default rules. Indeed, the myriad approaches reflected in the cases suggest this conclusion and lends support to the application of a purposive approach to the interpretation of ROFRs. Although adopting a fact-specific purposive approach may not promote the predictability of results that might be achieved by the application of default rules, it is more likely to result in decisions that reflect the reasonable expectations of the parties and also preserves greater flexibility in the drafting stage. Parties who want greater predictability should consider how to reflect their expectations with greater clarity when drafting the ROFR. By failing to address the issues that can arise more directly, partics run the risk of the vagaries inherent in having a court resolve the interpretation issues.

Considering the overall trend of the case law, it is arguable that Canadian courts, while struggling to ensure that ROFR rights are not easily capable of evisceration, are tending to give priority to the right of the vendor to alienate its property in the manner it deems most advantageous and will only give full effect to the rights of ROFR holders where the contract language reflects a clear intent to limit the owner's right of alienation in the specific circumstances. In addition, where ROFRs are triggered, the remedial trend in ROFR cases

18: However, the recent decisions of the Alberla Court of Queen's Bench in Apex. supra nole 64 and Investir financial, supra note 69, would indicate that a court would not likely lind favour with this type of argument.

(6) Such interesis are analogous to those arising under the CCAA (supra note 62) jurisprudence that the court in Bear Hills, sipra note 61 , relied upon as support for finding that the transaction did not trigger the ROFR. 
and in the case law generally, as well as the risks facing a ROFR holder who secks to prevent a potentially offensive transaction, suggest that it may become more difficult to enforce ROFR rights through injunctions and specific performance absent a clear expression of the purpose and intended application of the ROFR in the contract.

Assuming predictability of result is a desired goal, if parties are not prepared to more carefully address the scope of application of and purposes for including a ROFR clause at the drafting stage, the inherent unpredictability of result militates against the use of ROFRs as a restriction on disposition and their use in the industry will continue to decline. 